\title{
The recolonisation of volcanically disturbed Eocene habitats of Central Europe: the maar lakes of Messel and Offenthal (SW Germany) compared
}

\author{
Maryam Moshayedi ${ }^{1}$ - Olaf K. Lenz ${ }^{1,2} \cdot$ Volker Wilde $^{3} \cdot$ Matthias Hinderer $^{1}$
}

Received: 9 August 2019 / Revised: 8 January 2020 / Accepted: 26 March 2020 / Published online: 2 July 2020

(C) The Author(s) 2020

\begin{abstract}
To reconstruct the palaeoenvironment and changes within the vegetation, 68 core samples were analysed palynologically from the lacustrine filling of the Eocene maar lake of Offenthal (Hesse, SW Germany). The lacustrine succession includes $16 \mathrm{~m}$ of clastic sediments overlain by $13 \mathrm{~m}$ of finely laminated bituminous shale. Based on a revised ${ }^{40} \mathrm{Ar} /{ }^{39} \mathrm{Ar}$ age of $\sim 47.8 \pm 0.3 \mathrm{Ma}$, the lacustrine filling at Offenthal can be dated as uppermost lower Eocene to lowermost middle Eocene which is almost coeval to part of the nearby lacustrine succession at Messel. Cluster and non-metric multidimensional scaling (NMDS) analyses of well-preserved palynomorph assemblages reveal successional stages during the recolonisation of the maar lake and its surroundings which are related to lithological changes. Furthermore, the palynomorph assemblages from Offenthal are compared with assemblages from Messel by NMDS analysis to find similarities and differences during the recolonisation of volcanically disturbed habitats in Central Europe during Paleogene greenhouse conditions. Based on the similar succession in the vegetation at both lakes, four different phases can be distinguished during recolonisation and reestablishment of the vegetation at these sites: (1) an initial phase, (2) a recolonisation phase, (3) a recovery phase, (4) a climax phase.
\end{abstract}

Keywords Palynology $\cdot$ Eocene $\cdot$ Maar lake $\cdot$ Recolonisation $\cdot$ Multivariate analysis

\section{Introduction}

Since it was the last greenhouse period on Earth and ecosystems already consisted of modern-type floras and faunas, the Paleogene has been intensely studied to understand the response of ecosystems to environmental

Electronic supplementary material The online version of this article (https://doi.org/10.1007/s12549-020-00425-4) contains supplementary material, which is available to authorized users.

Maryam Moshayedi

moshayedi@geo.tu-darmstadt.de

1 Institute of Applied Geosciences, Applied Sedimentology, Technische Universität Darmstadt, Schnittspahnstrasse 9, 64287 Darmstadt, Germany

2 Senckenberg Gesellschaft für Naturforschung, Senckenberganlage 25, 60325 Frankfurt am Main, Germany

3 Sektion Paläobotanik, Senckenberg Forschungsinstitut und Naturmuseum, Senckenberganlage 25, 60325 Frankfurt am Main, Germany changes and climate variations. For the Eocene of Germany terrestrial ecosystems as described from the maar lake deposits of Messel (Gruber and Micklich 2007; Smith et al. 2018) and Eckfeld (Lutz et al. 2010), the lignites of the Geiseltal (Krumbiegel et al. 1983) as well as sites characterised by paralic settings such as the mining district of Helmstedt-Schöningen (Riegel et al. 2015; Riegel and Wilde 2016) are the best known examples. Palaeoenvironmental studies frequently focused on quantitative high-resolution palynology, e.g. for the maar lake of Messel (e.g. Lenz et al. 2007, 2015, 2017) or Lake Prinz von Hessen (Moshayedi et al. 2018).

There are at least half a dozen Eocene basins exposing lacustrine sediments known on the Sprendlinger Horst near Darmstadt in Southwest Germany (Fig. 1). Most of them are fillings of maar structures resulting from hydro-volcanic activity, such as Messel, Offenthal and Groß-Zimmern (Jacoby 1997; Harms et al. 1999; Jacoby et al. 2000; Felder et al. 2001; Felder and Harms 2004). Maar lake sediments are excellent for the 


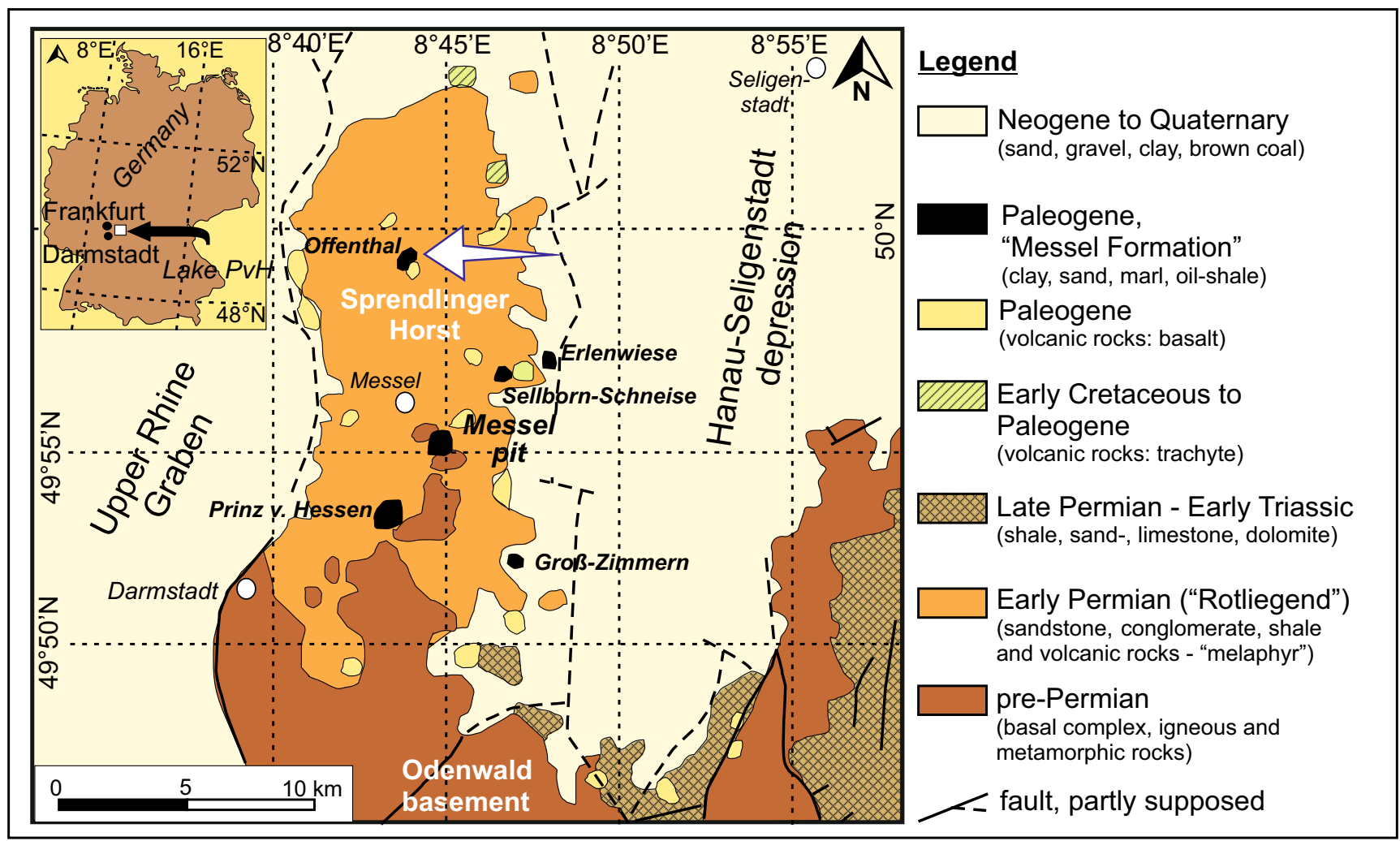

Fig. 1 Geological map of the Sprendlinger Horst (Southwest Germany) showing Lake Offenthal and other Paleogene sites in the area (modified from Harms et al. 1999; Lenz et al. 2007)

preservation of palaeoenvironmental information due to a considerable water depth in combination with a relatively small size of the lake. Anoxic conditions in the bottom water facilitate the excellent preservation of fossil remains (Sabel et al. 2005) and allow for high-resolution studies due to undisturbed and frequently finely laminated, sometimes varved sediments (Lenz et al. 2010). Therefore, the Sprendlinger Horst is offering the rare opportunity to study and compare almost coeval and nearby fillings of Paleogene maar lakes. The present palynological study of lacustrine sediments from the maar lake of Offenthal not only introduces another Eocene archive in the area but also especially allows for a comparison to the maar deposits of Messel that are worldwide known for an excellent preservation of fossils (Smith et al. 2018). Such a combination of spatial and temporal resolution is almost unique for Paleogene volcanic settings.

Our high-resolution palynological study is designed for providing insight into the recolonisation of a volcanically disturbed area by plants. Furthermore, it should aim to investigate by statistical analyses, whether the long- and short-term compositional changes of the vegetation are related to local facies changes in the depositional basin.

\section{The lacustrine succession at Offenthal}

Among the Paleogene maar lakes on the Sprendlinger Horst, Lake Offenthal is one of the smallest with a diameter of only 200-400 m (Felder et al. 2001). In order to find unequivocal proof for the origin of the basin, a scientific well $(\mathrm{B} / 98-\mathrm{BK} 1 \mathrm{E})$ was drilled in 1998 in the centre of the basin $\left(49^{\circ} 58^{\prime} 52.37^{\prime \prime} \mathrm{N}, 8^{\circ}\right.$ $44^{\prime} 40.88^{\prime \prime}$ E) to penetrate the lake sediments. A total of $80 \mathrm{~m}$ was cored of which the lower $51 \mathrm{~m}$ consist of volcanic rocks that can be separated from a lacustrine succession in the upper $29 \mathrm{~m}$ (Fig. 2). Based on lithological changes, Felder et al. (2001) divided the core in seven lithozones (LZ 1 to LZ 7), the lower two of them (LZs 1 and 2; Felder et al. 2001) of purely volcanic origin.

This part of the succession is followed by lacustrine sediments in which Felder et al. (2001) distinguished four lithozones (LZs 3-6) that became the focus of our study (Fig. 3). Representative parts of these lithozones are presented in Fig. 4; however, the complete photo documentation of the lacustrine succession is included in the online supplementary material.

LZ 3 between 29.40 and $22.20 \mathrm{~m}$ is characterised by the dominance of turbiditic beds of conglomerates and 


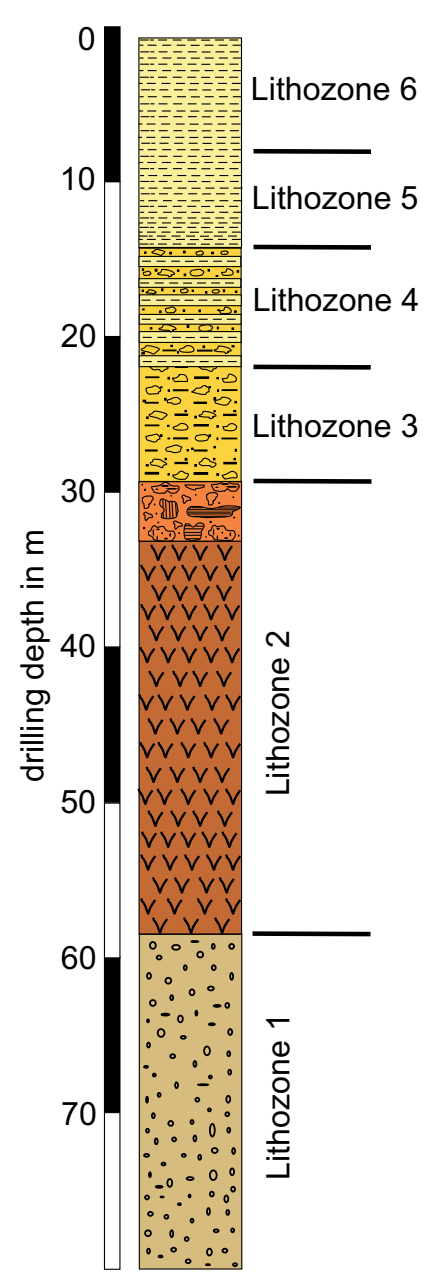

Offenthal

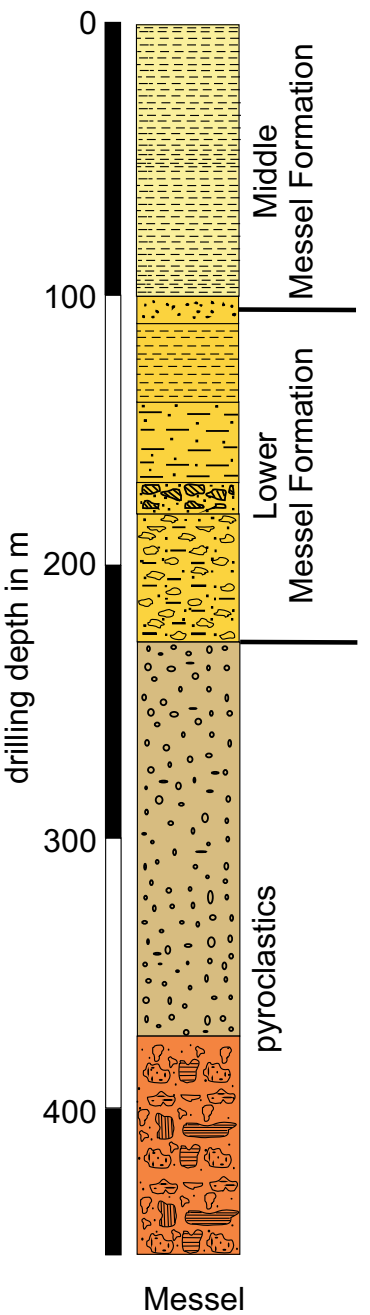

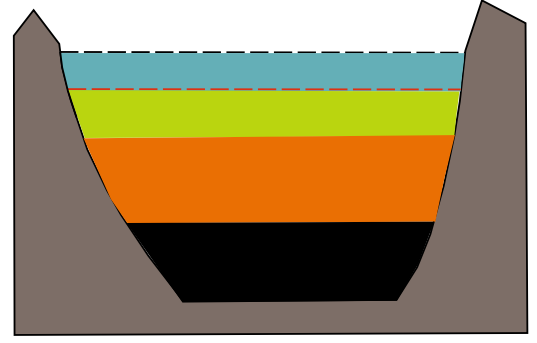

Lake Messel

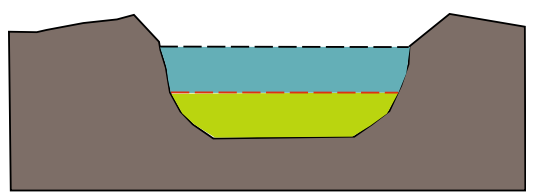

Lake Offenthal

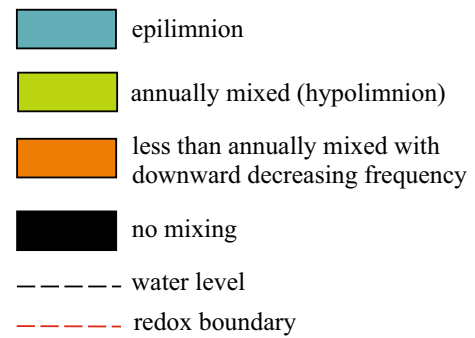

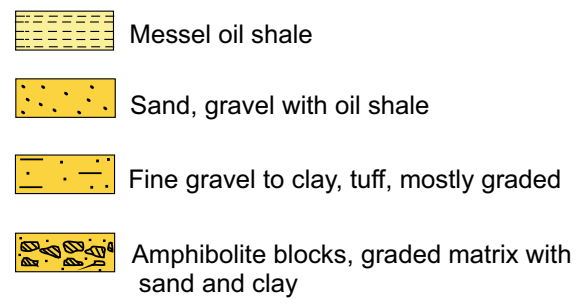

Fig. 2 a Generalised sections of the Messel and Offenthal cores modified after Felder et al. (2001) and Felder and Harms (2004). b Sketches of the maar lakes of Messel and Offenthal indicating meromixis and a

\section{$. \overline{-\infty} \cdot \overline{-}:$ Gravel to clay, tuff, mostly graded \\ $v_{V} v_{V} V^{2}$ Breccia and Basalt \\ Lapilli tuff \\ Breccia (amphibolite, granite, granodiorite, Rotliegend-sandstone), graded}

permanently stratified lake at Messel and annual overturn with only seasonal stratification at Lake Offenthal (modified from Felder and Gaupp 2006)

massive to finely bedded or laminated (Figs. 3 and 4b, c). The increasing content of organic material in LZ 4 compared with LZ 3 is also indicated by the darker colour of the sediment (Fig. 4b, c).

In LZ 5 between 14.07 and $8.25 \mathrm{~m}$, bituminous shales are dominant (Felder et al. 2001). Beds with coarser clastic layers or individual turbidites occur only occasionally (Figs. 3 and 4d). This indicates an increasing stability of the crater walls (see increase in layers of bituminous silt and clay, which appear 

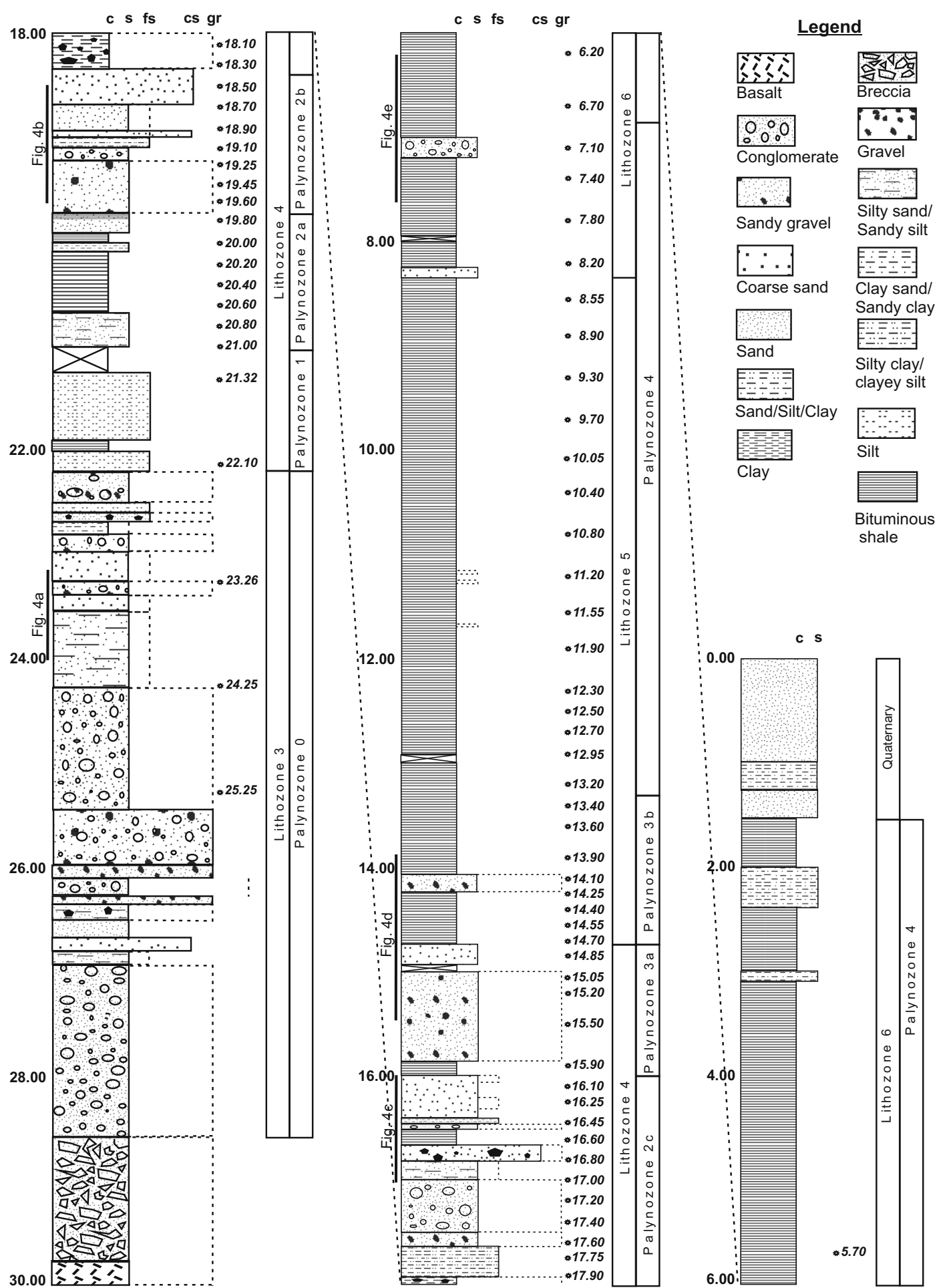

Fig. 3 Generalised section of the core Offenthal showing lithozones and palynozones as used in this paper. The position of core images as provided on Fig. 4 is indicated

Lenz et al. 2007). The same as for LZ 5 also applies to LZ 6 between 8.25 and $1.8 \mathrm{~m}$. However, in contrast to LZ 5, the bituminous shales are often finely laminated (Fig. 4e) and frequently interspersed with siderite laminae (Felder et al. 2001).
The lacustrine succession of LZs 3 to 6 documents the gradual and continuous filling of the basin without unconformities and disturbance. The succession is finally cut by Quaternary sediments at a depth of $1.8 \mathrm{~m}$ (Fig. 3). 
(a)

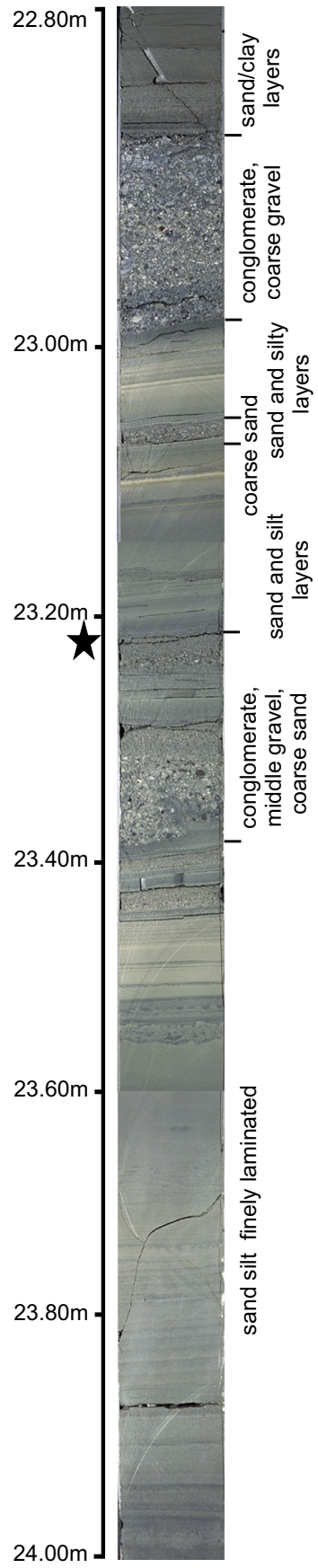

(b)

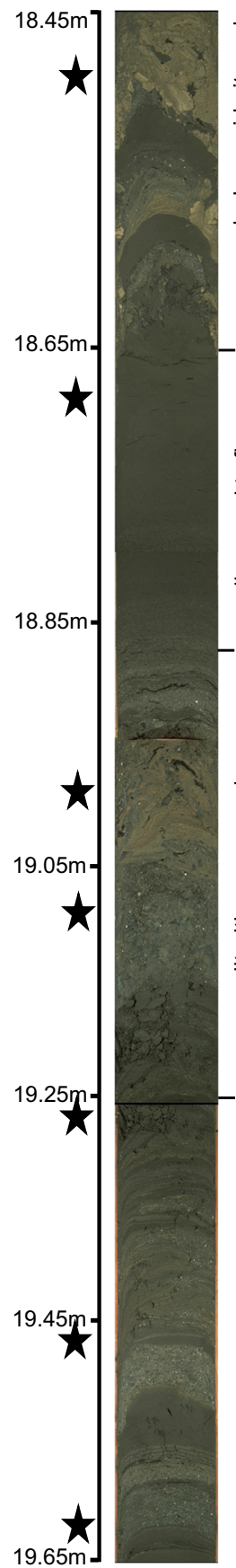

(c)

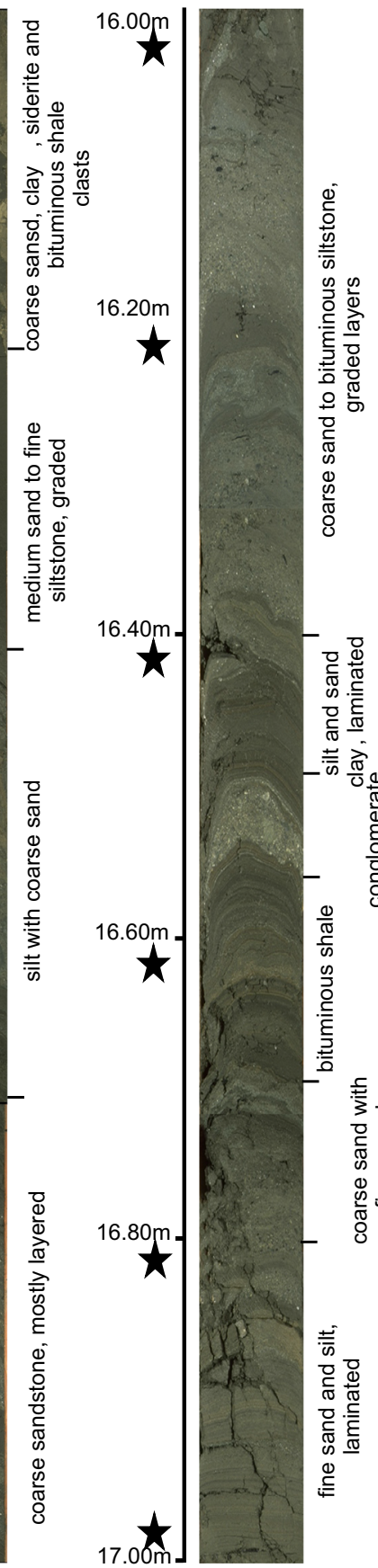

(d)

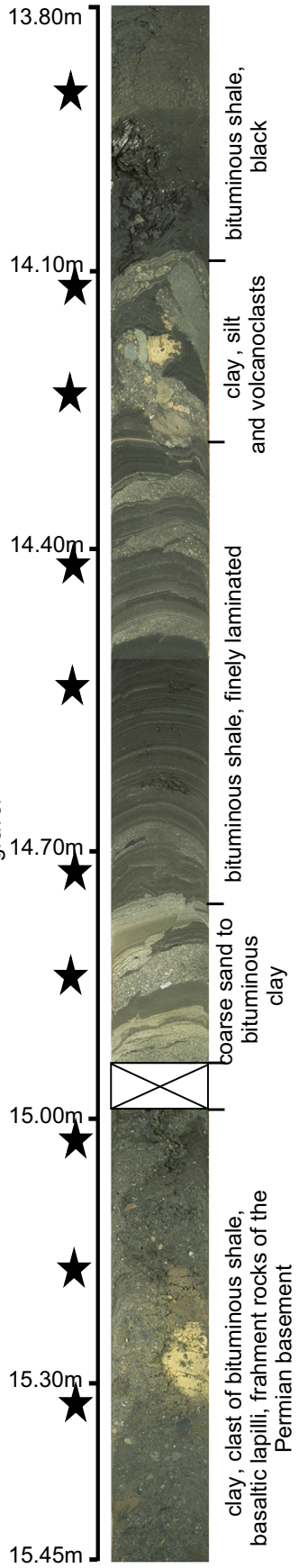

(e)

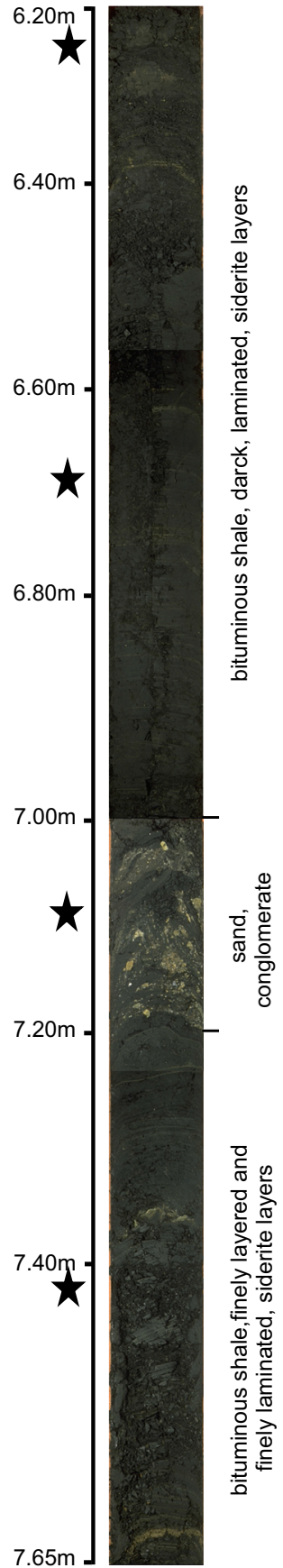

Fig. 4 Selected images of the core illustrating the lacustrine record of Offenthal and its lithozones. The position of the respective palynological samples is indicated by black stars. The pictures are based on photographs of FIS/HLUG (F.J Harms, W. Schiller and M.

\section{Material and methods}

\section{Sampling and sample processing}

For palynological investigation of the lacustrine sediments of the Offenthal core between $25.25 \mathrm{~m}$ and $5.70 \mathrm{~m}, 68$ samples were analysed at approximately $20 \mathrm{~cm}$ intervals. Samples
Stryj) from the core BK 1E. a LZ 3, 11034.pcd-11037.pcd; b LZ 4, 11024.pcd-11026.pcd; c LZ 4, 11018.pcd-11020.pcd; d LZ 4/5, 11013.pcd-11016.pcd; e LZ 6, 10995.pcd-10998.pcd

were prepared using standard palynological extraction techniques as described by Kaiser and Ashraf (1974). They were successively treated by hydrochloric acid (HCL), hydrofluoric acid $(\mathrm{HF})$ and potassium hydroxide $(\mathrm{KOH})$. To improve transparency of the palynomorphs after sieving through a $10-\mu \mathrm{m}$ mesh screen, the residues were briefly oxidised by applying nitric acid $\left(\mathrm{HNO}_{3}\right)$ or hydrogen peroxide $\left(\mathrm{H}_{2} \mathrm{O}_{2}\right)$. For each 
sample, one or more permanent slides have been prepared by mixing the residue with glycerin jelly. Slides and residues are housed at the Senckenberg Research Institute und Natural History Museum, Section Paleobotany, Frankfurt am Main, Germany.

\section{Quantitative palynological analysis}

Palynological analysis was undertaken by using a transmitted light microscope (Olympus BX40). At least 250 individual palynomorphs per sample were identified and counted at $\times 400$ magnification to obtain a representative and robust data set that can be used for statistical analysis. The raw data are included in the supplementary material. However, 10 to $15 \%$ of the total assemblages could not be determined due to poor preservation and were counted as "Varia". The palynomorphs (complete list in supplementary Table 1) were identified based on the systematic-taxonomic studies of Thomson and Pflug (1953), Thiele-Pfeiffer (1988), Nickel (1996) and Lenz (2005).

The pollen diagram, produced by PanPlot 11.04 (Alfred Wegener Institut für Polare und Marine Forschung, PANGEA), shows the abundance of the most important palynomorphs in percentages. To arrange the taxa according to their weighted average value (WA regression; ter Braak and Looman 1995), software C2 1.7.6 (Juggins 2007) was used because such an arrangement of pollen is necessary to obtain a structured pollen diagram that shows the major patterns of compositional variation in relation to depth and reveals progressive steps in the evolution of the plant community (Janssen and Birks 1994). Pollen and spores were calculated to $100 \%$, whereas algae such as Botryococcus and Ovoidites were recorded as additional percentages in percent of the total pollen sum.

Statistical analysis (cluster analysis and non-metric multidimensional scaling)

For a robust zonation of the pollen diagram, constrained cluster analysis was carried out using the unweighted pair group average method (UPGMA), an agglomerative hierarchical clustering method. Furthermore, to illustrate compositional differences and ecological trends between the different vegetation phases at Offenthal and to compare the vegetation at Offenthal with the vegetation at Messel, non-metric multidimensional scaling (NMDS; Shepard 1962a, b; Kruskal 1964) has been performed. For cluster analysis and NMDS, software PAST 3.23 has been used (Hammer et al. 2001).

To avoid possible sources of error which can have an impact on the results, the palynological data set was simplified for statistical analysis. Some of the palynomorph taxa were lumped to minimise problems in the identification to "species level" and therefore potential identification errors, because of minor differences between some of the species, e.g. species of the juglandaceous genera Plicatopollis and Plicapollis. Furthermore, for cluster analysis and NMDS, all taxa have been removed that did not reach $1 \%$ in any of the studied samples. Therefore, for multivariate analysis of the Offenthal data, a reduced number of 40 palynological "variables" were used (Supplementary Table 1). For the joint NMDS of the Offenthal and Messel data, the number of palynological "variables", which are typical for both records, slightly increased to 54 (Supplementary Table 1).

Statistical analysis is based on the raw data, which have been standardised using the Wisconsin double standardisation (Bray and Curtis 1957; Cottam et al. 1978; Gauch and Scruggs 1979; Oksanen 2007). This standardisation method scales the abundance of each taxon to its maximum value and represents the abundance of each taxon by its proportion in the sample (Mander et al. 2010). This removes the influence of sample size on the analysis and equalizes the effects of rare and abundant taxa on clustering and NMDS (Van Tongeren 1995; Jardine and Harrington 2008). As a similarity measure, we used the Bray-Curtis dissimilarity for all analyses.

NMDS has been chosen as the appropriate ordination method, because NMDS is the most robust unconstrained ordination method in ecology (Minchin 1987) and has been successfully applied to palynological data in previous studies (e.g. Oswald et al. 2007; Jardine and Harrington 2008; Mander et al. 2010; Ghilardi and O'Connell 2013; Broothaerts et al. 2014; Lenz and Wilde 2018). Compared with other ordination techniques of multivariate data such as principal component analysis or (detrended) correspondence analysis, NMDS avoids the assumption of a linear or a unimodal response model between the palynomorph taxa and the underlying environmental gradients, and as a nonparametric method, it also avoids the requirement of normality of data. NMDS uses ranked, rather than absolute, distance values to project the data into a two- or three-dimensional coordinate system (ter Braak 1995; Hammer et al. 2006).

For the joint NMDS of palynomorph assemblages from Lake Offenthal and Lake Messel, quantitative palynological data of 598 samples from Messel (Lenz and Wilde 2018) have been used. Compared with Lenz and Wilde (2018), the original Messel data set of 680 samples has been reduced by 82 samples by cutting off outliers in the data set which are characterised by specific palynomorph contents that do not represent typical assemblages of different evolutionary stages of the vegetation at Messel. Furthermore, the 10 different vegetation phases (Lenz et al. 2007; Lenz et al. 2011; Lenz and Wilde 2018) which have previously been distinguished at Messel were reduced to five phases including two phases from the Lower Messel Formation with the Early Initial Lake Phase (EILP) and the Late Initial Lake Phase (LILP) and three phases of the Middle Messel Formation (MMF). Phase "MMF base" includes phases MMF 1 and 2, "MMF centre" 
phase MMF 3 and "MMF top" phases MMF 4 to 6 of Lenz and Wilde (2018).

\section{Results}

Age determination for Lake Offenthal

A basaltic clast from the top of volcanoclastic material of LZ 2 that may serve as evidence for the time of the eruption was dated at $47.4 \pm 0.3 \mathrm{Ma}$ applying the ${ }^{40} \mathrm{Ar} /{ }^{39} \mathrm{Ar}$ incremental heating technique (Mertz and Renne 2005). However, according to a revised calibration of the ${ }^{40} \mathrm{Ar} /{ }^{39} \mathrm{Ar}$ system in the Fish Canyon sanidine as age reference material (FCs; see Lenz et al. 2015 for details), the eruption at Offenthal happened 300 to $500 \mathrm{ka}$ earlier than previously assumed at $47.71 \pm$ 0.3 Ma using a new FCs age of Kuiper et al. (2008), and $47.87 \pm 0.3 \mathrm{Ma}$ using a recalibrated FCs age provided by Renne et al. (2011). According to the ICS International Chronostratigraphic Chart, the Ypresian/Lutetian boundary is now fixed almost exactly at 47.8 Ma (Cohen et al. 2013). Therefore, the lacustrine filling at Offenthal should be regarded as uppermost lower Eocene to lowermost middle Eocene in age.

Compared with the eruption at Messel with an age of 48.27 \pm 0.22 (based on the FCs age of Kuiper et al. 2008, see Lenz et al. 2015) or $48.11 \pm 0.22$ (FCs age of Renne et al. 2011, see Lenz et al. 2015), the eruption at Offenthal happened c. $300 \mathrm{ka}$ later. However, since deposition at Messel lasted c. $900 \mathrm{ka}$ (Lenz et al. 2015), the lacustrine sediments at Offenthal probably were deposited contemporaneously to the younger part of the Middle Messel Formation at Messel.

\section{Palynology of Lake Offenthal}

The occurrence and distribution of the most abundant palynomorphs throughout the lacustrine succession of Lake Offenthal are shown in the pollen diagram (Fig. 5). Based on constrained cluster analysis, five palynozones (PZs 1 to 5) have been distinguished (Fig. 6). They are characterised by specific palynomorph assemblages and can be correlated to the LZs of Felder et al. (2001) (Figs. 3 and 6). A sixth and lowest palynozone (PZ 0 ) is created in the pollen diagram for the lowermost three samples at 25.25, 24.25 and 23.26 $\mathrm{m}$ from the lacustrine part of the core (Fig. 5). These samples rarely show any palynomorphs and counts are without any statistical significance. In the lower two samples, only 14 and 12 palynomorphs and in the sample at $23.26 \mathrm{~m}$ depth only 135 palynomorphs have been identified by scanning several slides. Therefore, they have been separated from the other samples which contain abundant and well-preserved palynomorphs.

Compositional differences between the pollen assemblages in PZs 1 to 5 become evident in the NMDS plot (Fig. 7), because samples from the oldest PZ 1 up to the youngest PZ 5 are ordered from right to left in the ordination space of the NMDS plot.

\section{Palynozone 1}

PZ 1 is represented by only two samples from 22.10 and $21.32 \mathrm{~m}$ depth from the lower part of LZ 4 (Figs. 3 and 6). These samples plots in the upper right corner of the NMDS ordination space are clearly separate from the other samples due to significant differences in composition compared with the palynomorph assemblages of the other samples (Fig. 7a). Spores of Schizaeaceae with different species of Leiotriletes spp. (up to $28 \%$, Fig. 8 d, e) and Trilites spp. (up to $12 \%$ ) are particularly abundant. These taxa have also been recognised with some grains in PZ 0. Other fern spores such as Tegumentisporites spp. (Selaginellaceae, up to 2\%) and Polypodiaceoisporites spp. (Polypodiaceae, up to $3 \%$, Fig. 8i) appear also regular in this PZ.

Among the swamp forest elements, Inaperturopollenites spp. (Cupressaceae, Fig. 8b, c) reach their maximum for the complete section with $7 \%$. Further dominant elements are Plicatopollis spp. (Juglandaceae, up to 18\%, Fig. 9i) and Tricolporopollenites cingulum (Fagaceae, up to 18\%, Fig. 9k, 1).

Remarkable is the poor preservation of palynomorphs in these two samples which is indicated by the highest amount of unidentified palynomorphs ("Varia") in the record at Offenthal.

\section{Palynozone 2 and its subdivisions}

PZ 2 occurs between 21.00 and $16.10 \mathrm{~m}$ depth and consists of 27 samples (Fig. 6). Due to minor differences in the palynomorph composition, it can be subdivided in three parts: PZ 2a with 7 samples between 21.00 and $19.80 \mathrm{~m}$, followed by PZ $2 \mathrm{~b}$ with 6 samples up to a depth of $18.70 \mathrm{~m}$ and finally PZ 2c with 14 samples in the upper $2.60 \mathrm{~m}$ of PZ 2. The zone comprises most of LZ 4 in which bituminous shales become more and more abundant.

In the NMDS, the samples are plotted at the right side of the ordination space (Fig. 7a). Most samples of PZ 2a are in the lower right corner, whereas samples of zones PZ $2 b$ and PZ 2c are plotted near the centre of the ordination space. Therefore, a continuous change within the palynomorph assemblages between PZ 2a and PZ 2c is indicated.

The dominant fern spores of PZ 1 such as Trilites spp. and Leiotriletes spp. are still present in PZ 2, but steadily decreasing towards PZ 2c. Other fern spores, such as Punctatosporites palaeogenicus (Fig. 8k), a spore of the Polypodiaceae, are limited to PZ 2 with a maximum value of $3 \%$. Spores of other Polypodiaceae (Polypodiaceoisporites spp.) which are distributed throughout the Offenthal record reach their maximum here. 


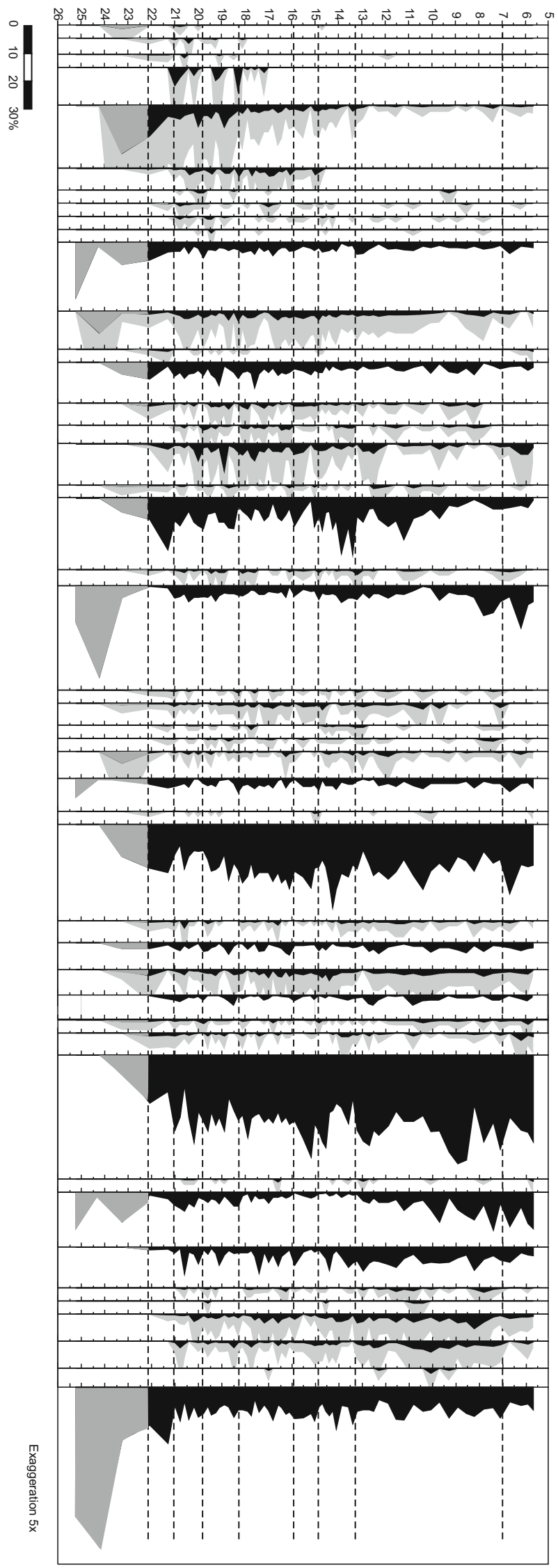

Depth (meter)

Ischyosporites tertiarius (S)

Tricolpopollenites quisqualis $(P)$

Botryococcus (A)

Trilites spp. (S)

Milfordia spp. (P)

Tricolporopollenites microporitus $(P)$

Punctatosporites palaeogenicus (S)

Tricolporopollenites eofagoides (P)

Inaperturopollenites spp. (P)

Celtipollenites spp. (P)

Tegumentisporites spp. (P)

Tricolporopollenites microreticulatus $(P)$

Porocolpopollenites rarobaculatus $(P)$

Emmapollis pseudoemmaensis $(P)$

Polypodiaceoisporites spp. (S)

Tricolporopollenites marcodurensis $(P)$

Leiotriletes spp. (S)

Intratriporopollenites spp. (P)

Pityosporites labdacus $(\mathrm{P})$

Momipites spp. (P)

Subtriporopollenites magnoporatus $(P)$

Verrucatosporites favus (S)

Tricolporopollenites mansfeldensis $(\mathrm{P})$

Laevigatosporites spp. (S)

Plicapollis spp. (P)

Interpollis spp. (P)

Plicatopollis spp. (P)

Tricolpopollenites retiformis $(\mathrm{P})$

Tricolporopollenites edmundi group $(P)$

Platycaryapollenites spp. (P)

Tetracolporopollenites spp. (P)

Nyssapollenites kruschi spp. ( $P$ )

Nudopollis terminalis hastaformis $(\mathrm{P})$

Tricolporopollenites cingulum $(\mathrm{P})$

Monocolpopollenites spp. (P)

Tricolpo(ro)pollenites parmularius $(P)$

Tricolpopollenites liblarensis $(P)$

Punctilongisulcites microechinatus (S) Entophlyctis lobata (F)

Tricolpopollenites vegetus $(P)$

Tricolporopollenites crassostriatus $(\mathrm{P})$

Ovoidites (A)

Varia

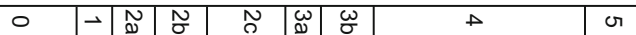


Fig. 5 Pollen diagram showing the most important taxa in the lacustrine succession of Lake Offenthal. The diagram shows the five palynological zones as derived from constrained cluster analysis (see Fig. 6). A, algae; $\mathrm{P}$, pollen; $\mathrm{S}$, spore; F, fungal spore

Some taxa such as Milfordia spp. (Restionaceae, up to 5\%; Fig. 9a), Emmapollis pseudoemmaensis (Chloranthaceae, up to 3\%; Fig. 9q), Pityosporites labdacus (Pinaceae, up to 5\%; Fig. 8a), Intratriporopollenites spp. (Malvaceae, up to 4\%; Fig. 8g), Tricolporopollenites crassostriatus (Solanaceae, up to 2\%) and Tricolpopollenites vegetus (Hamamelidaceae, up to 6\%; Fig. 9b) have their first appearance for Offenthal in this PZ.

Among the dominant elements, the increase of Tricolporopollenites cingulum in comparison with zone PZ 1 is noteworthy. With up to $32 \%$, this taxon is by far the most common in PZ 2. Plicatopollis spp. (up to 24\%) are also much more common than in PZ 1 and increase continuously from PZ 2a to PZ 2c.

The subdivision of PZ 2 is mainly based on the decreasing abundance of fern spores and increasing values of Plicatopollis spp. However, also the occurrence of less abundant palynomorphs differs between the three subzones. PZ 2a, for example, is characterised by the regular appearance of Bombacacidites spp. (Malvacaceae; Fig. 81), Tricolporopollenites pseudocingulum and Tricolporopollenites quisqualis (both fagaceous alliance), while these elements disappear in zones PZ 2b and PZ 2c. Furthermore, the coccal green alga Botryococcus is relatively abundant in $\mathrm{PZ} 2 \mathrm{a}$ and $\mathrm{PZ} 2 \mathrm{~b}$ with a maximum value of $9 \%$, but lacks completely in PZ 2c and the rest of the core.

\section{Palynozone 3 and its subdivisions}

PZ 3 consists of 13 samples between 15.90 and $13.40 \mathrm{~m}$ depth and is subdivided in subzones PZ 3 a (5 samples up to $14.85 \mathrm{~m}$ ) and PZ 3b (8 samples up to $13.40 \mathrm{~m}$ ). This subdivision clearly correlates to the lithological change between LZ 4 and LZ 5 (Figs. 3 and 6). LZ 5 is characterised by the deposition of bituminous shales.

The samples of PZ 3 are plotted near the centre of the NMDS ordination space, but samples of zone PZ $3 \mathrm{a}$ are more on the positive side of NMDS axis 1 together with samples from PZ 2c, whereas samples of zone PZ 3b are more on the negative side of axis 1 together with samples from the following PZ 4 (Fig. 7a). This shows that PZ 3 is a transitional phase between the older (PZ 2) and the younger (PZ 4) vegetation.

A transitional phase is indicated by the complete disappearance of Restionaceae (Milfordia spp.) at the end of PZ 3a, while fern spores of Trilites spp. nearly disappear at the end of PZ 3b. Both elements are among the dominant species in the older zones PZ 1 and PZ 2. In contrast, taxa such as Tricolpopollenites liblarensis (Fig. 9j) or T. vegetus start to increase in abundance in PZ $3 \mathrm{~b}$ towards values which are characteristic for the younger zones PZ 4 and PZ 5.

Among the dominant elements, Tricolporopollenites cingulum and Plicatopollis spp. also increase in abundance in comparison with the older PZs. T. cingulum reaches a peak abundance with $37 \%$ in PZ 3a, while Plicatopollis spp. have their highest abundance for the complete record with $30 \%$ in PZ 3b. Furthermore, fern spores of Leiotriletes spp. (up to $21 \%$ ) also have their maximum in PZ 3b. Another polypodiaceous spore (Verrucatosporites favus; Fig. 8f) occurs regularly in $\mathrm{PZ} 3 \mathrm{~b}$ but is almost missing otherwise at Offenthal.

\section{Palynozone 4}

PZ 4 between 13.20 and $7.10 \mathrm{~m}$ includes 19 samples of LZ 5 and the lower part of LZ 6 (Figs. 3 and 6). The samples are plotted in the NMDS at the left negative side of axis 1 in the ordination space, clearly separate from samples of the younger PZs 1 to 3b (Fig. 7a). Only samples of PZ 3b are plotted together with some samples of PZ 4 at the centre of the ordination space, indicating similar palynomorph assemblages.

Some palynomorph taxa show a strong increase in their abundance compared with older PZs (Fig. 5). Tricolpo(ro)pollenites parmularius (Eucommiaceae; Fig. 9n) regularly occurs with low values in PZ 1 to PZ 3 but increases strongly in its abundance from c. $3 \%$ at the base of PZ 4 to $14 \%$ at the top of the PZ. Tricolporopollenites cingulum (up to 40\%), T. vegetus (up to 6\%) and Pityosporites spp. (up to $11 \%$ ) also increase in abundance from the lower to the upper part of PZ 4. Plicatopollis spp. (up to 24\%) and Tricolpopollenites liblarensis (up to 9\%) are characterised by keeping high values.

In contrast, fern spores of Trilites spp. and especially of Leiotriletes spp. show a strong decrease to relatively low numbers compared with PZs 3 and 2. Milfordia spp., prominent in PZ 2 and PZ 3, are completely missing in PZ 4.

Also remarkable is the occurrence of Ovoidites which represents cysts of freshwater algae (Zygnemataceae) in some samples of PZ 4.

\section{Palynozone 5}

Four samples from the top of the studied section between 6.70 to $5.70 \mathrm{~m}$ (LZ 6) have been put together in PZ 5. In the cluster analysis, these samples are clearly distinguished from all other samples (Fig. 6) and plotted on the left side of the NMDS

Fig. 6 Results of a constrained cluster analysis (UPGMA) of 68 samples between 21.10 and $5.70 \mathrm{~m}$. Samples are labelled with their core depth in meters. The separation into five pollen zones correlates well with lithological changes 


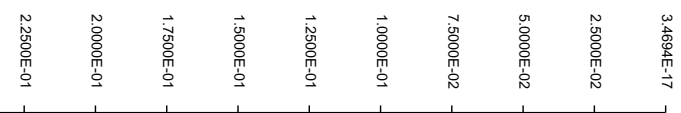

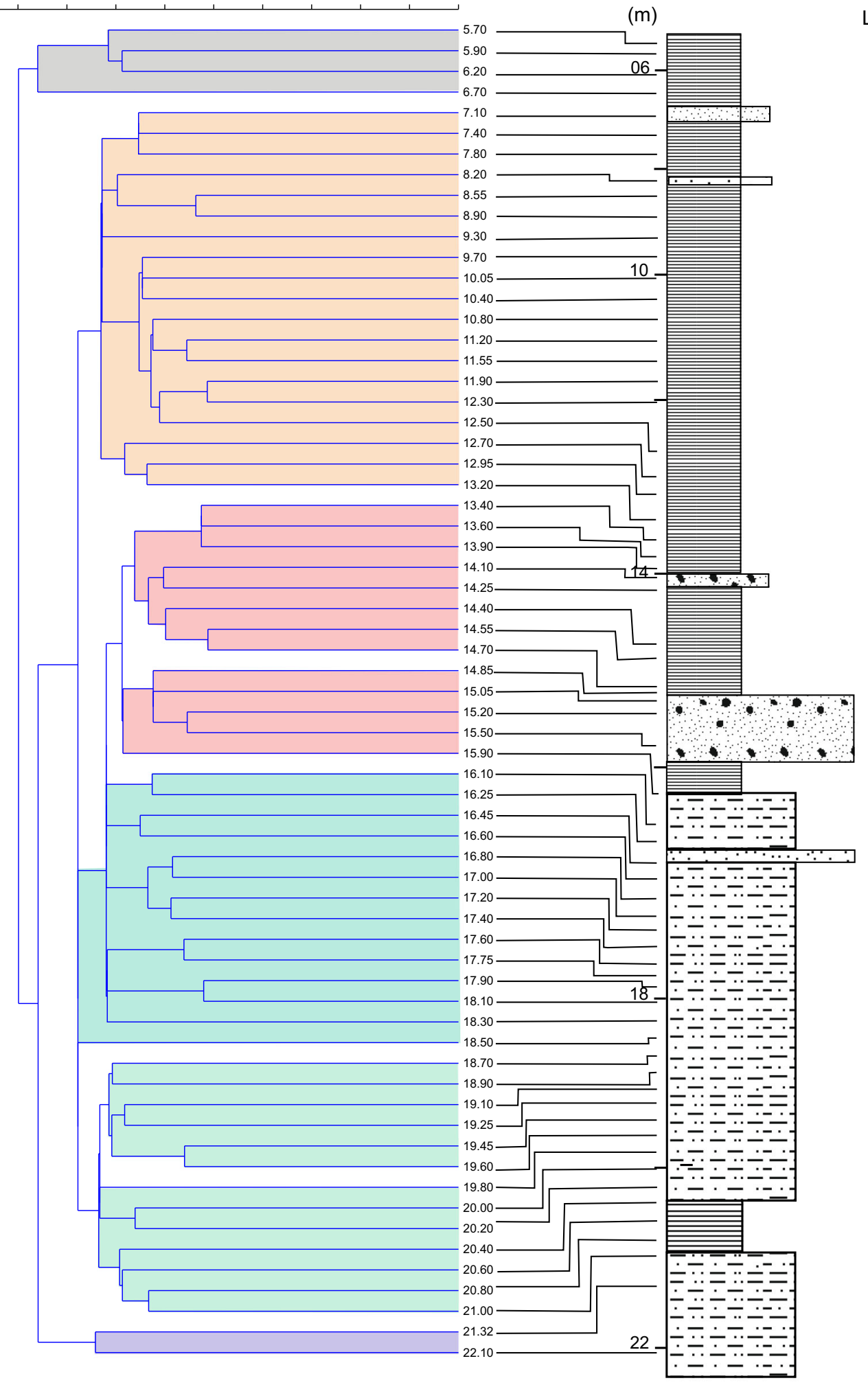

\section{Lithozone Palynozone}
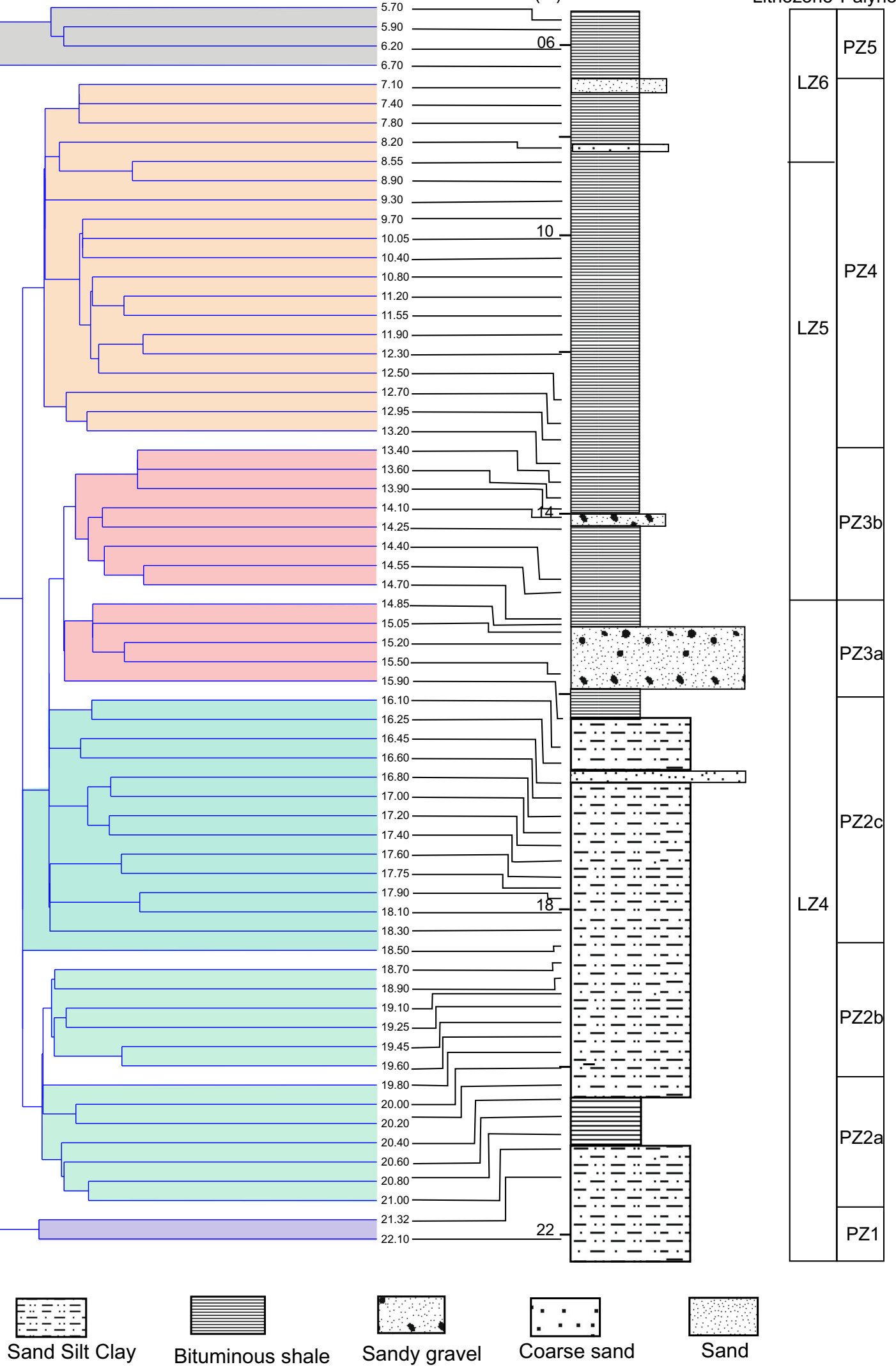
a)
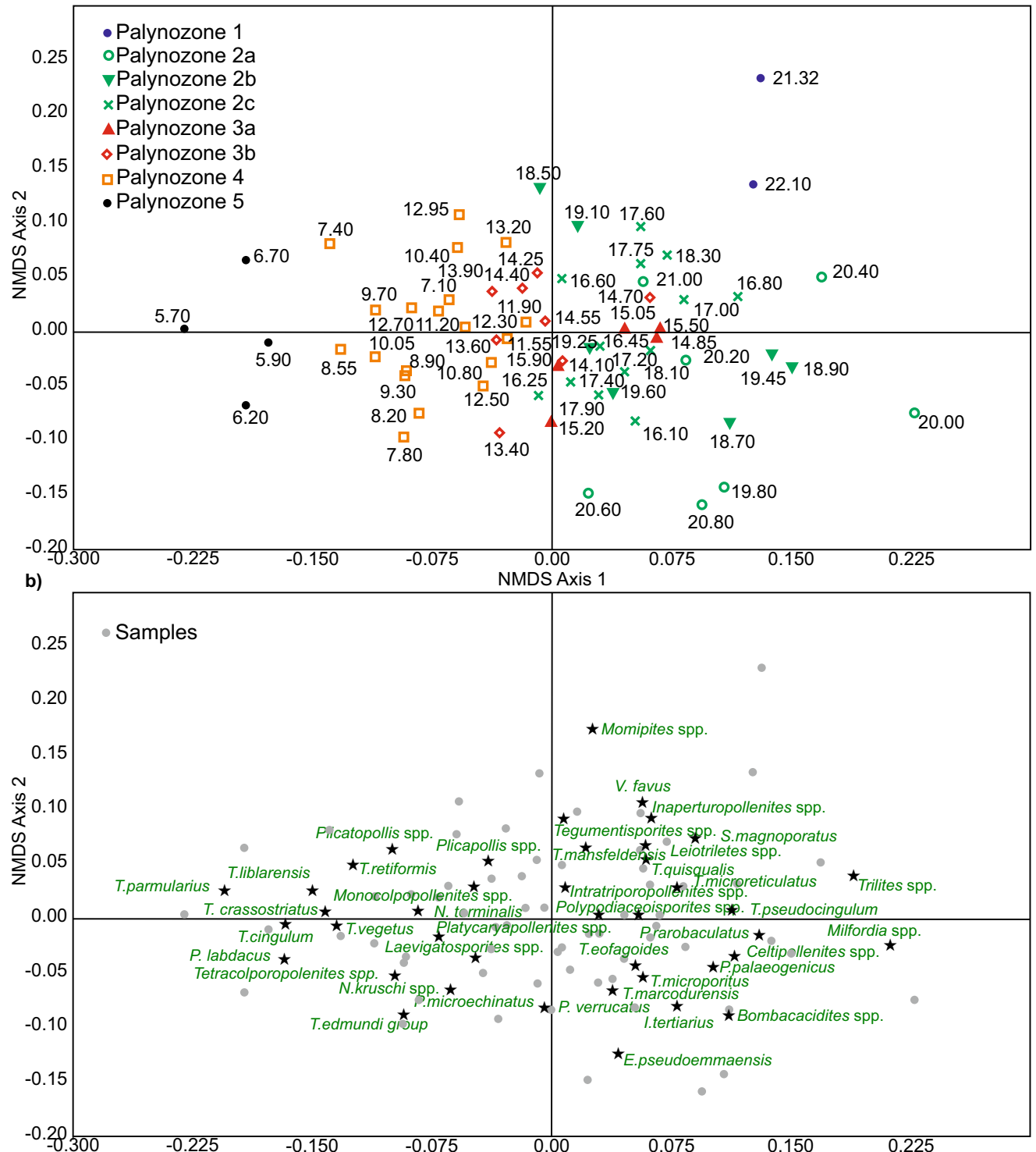

c)

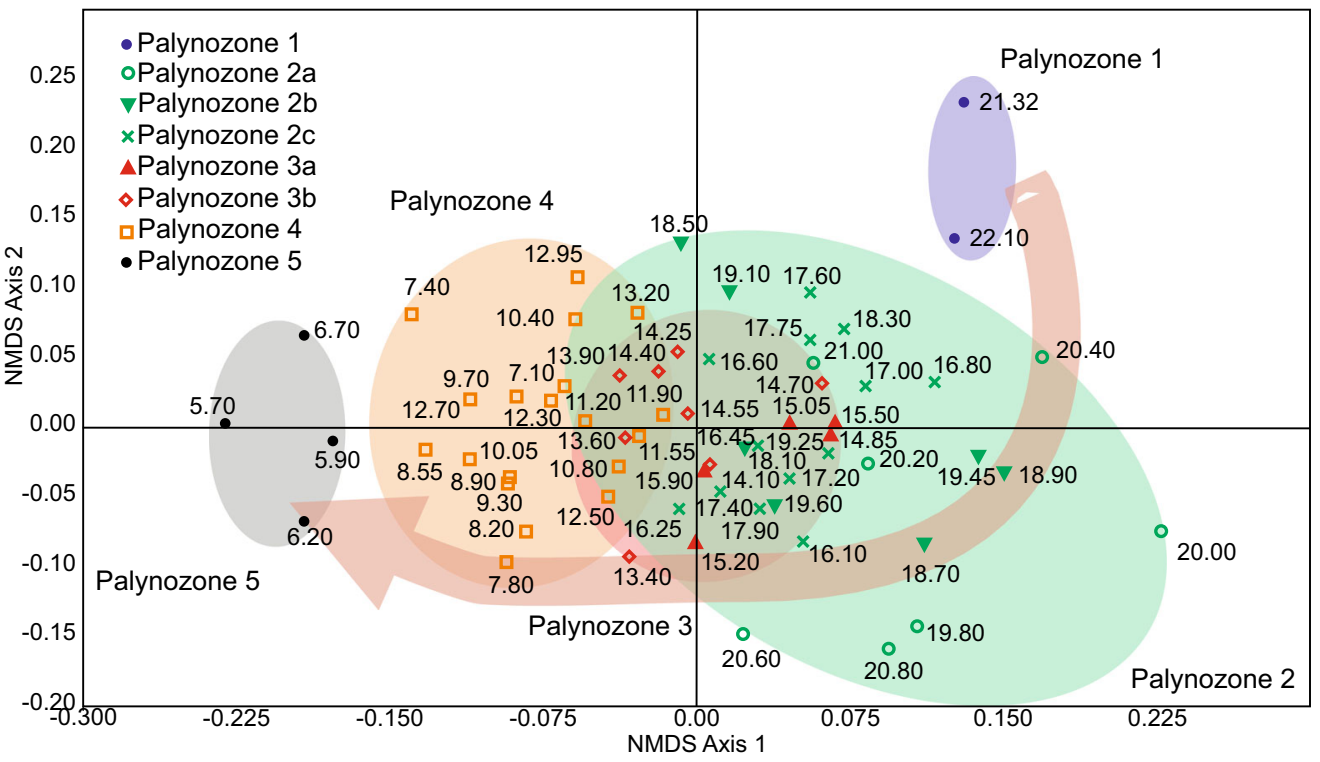


Fig. 7 Non-metric multidimensional scaling (NMDS) of palynological data of 68 samples from the lacustrine succession of the Offenthal maar lake using the Bray-Curtis dissimilarity and the Wisconsin double standardised raw data values. a Scatter plot of the first two axes showing the arrangement of samples. The different symbols represent samples from the five different palynozones. b Scatter plot of the first two axes showing the arrangement of taxa. The dots represent the different samples (see a). c Scatter plot of the first two axes showing the arrangement of palynozones and samples. The arrow illustrates the temporal succession of palynozones

ordination space relatively far away from the other samples on the negative end of axis 1 indicating significant compositional differences compared with the other samples (Fig. 7a). This depends mainly on the maximum distribution of Pityosporites labdacus (up to 16\%) in combination with high values of Tricolpo(ro)pollenites parmularius (up to $13 \%$ ), Tricolporopollenites cingulum (up to 25\%) and Plicatopollis spp. (up to 15\%). Furthermore, the Normapolles element Nudopollis terminalis (myricaceous/juglandaceous alliance; Fig. 9e) has its peak abundance in PZ 5 with up to $3 \%$.

\section{Discussion}

Reconstruction of the palaeoenvironment at Lake Offenthal

After the eruption(s) at Offenthal had ceased, the newly formed barren surface of the crater wall and the surrounding devastated area were gradually re-occupied by the vegetation in a similar way as described for Lake Messel by Lenz et al. (2007). Recolonisation at Offenthal started with elements of a pioneering vegetation such as different ferns (Fig. 5). During the recolonisation process, the zonal vegetation re-advanced and completely re-occupied the area at the end of the time which is documented in the lacustrine deposits of the crater. This is seen in the pollen record as presented in the pollen diagram (Fig. 5) and especially in the NMDS plot of the taxa. Samples from the oldest PZ 1 up to the youngest PZ 5 are ordered from right to left in the ordination space of the NMDS plot indicating a continuous change in the composition of the vegetation throughout the different palynozones (Fig. 7c).

The different distribution of early colonisers such as ferns represented by spores such as Leiotrilites spp., Trilites spp., Verrucatosporites favus and Polypodiaceoisporites spp. in PZ 1, PZ 2 and PZ 3a, which are plotted on the right side of the NMDS ordination space (Fig. 7b) reveal a successive vegetational recolonisation in the lower part of the record. During PZ 3b, PZ 4 and PZ 5, the re-advance of the (para)tropical rainforest in the crater area is obvious. This is indicated especially by pollen of Juglandaceae (e.g. Plicatopollis spp. and Plicapollis spp.) and Fagaceae (e.g. Tricolporopollenites cingulum and Tricolporopollenites liblarensis), which became more and more dominant in the younger PZs and are therefore plotted at the left side of NMDS axis 1 (Fig. 7b). At the same time, the herbaceous pioneering community represented by diverse fern spores decreased. Taking into account the sediments at the base of the lacustrine succession, which are almost free of palynomorphs (PZ 0), three phases can be distinguished in the recolonisation of the volcanically disturbed site at Offenthal by plants.

\section{Initial phase}

An initial recolonisation phase is represented by PZ 0, composed of three samples from the lowermost part of the lacustrine succession. Except for single badly preserved pollen of Pinaceae (Pityosporites spp.), Cupressaceae (Inaperturopollenites spp.), Juglandaceae (Plicatopollis spp.), Eucommiaceae (Tricolpo(ro)pollenites parmularius) and a couple of fern spores, these samples are barren of palynomorphs.

Since these three samples originate from the base of the lacustrine succession which is lithologically characterised mainly by coarse-grained turbidites (LZ 3, Felder et al. 2001), it can be assumed that the sediments were deposited rapidly after the end of the eruption while a lake formed in the crater and material was sliding from the unstable crater slopes into the lake. During this phase, the crater area was almost free of vegetation. However, rare but diverse fern spores such as Ischyosporites tertiarius, Trilites sp., Leiotriletes spp. and Laevigatosporites spp. probably indicate that initial colonisation of the area by ferns already had started (Fig. 10a). Few pollen grains were transported into the lake by wind from the zonal vegetation surviving in the distance (Fig. 10a). This is especially supported by pinaceous pollen, which is wind dispersed and may be transported over longer distances. The deposition of wind-dispersed pollen such as those of Pinaceae or Cupressaceae may even be regarded as typical for the basal part of lacustrine successions in crater lakes (Rampino and Koeberl 2006). Rare evidence of pollen of Juglandaceae or Eucommiaceae can also be regarded as representing the distant (para)tropical forest (Boulter and Hubbard 1982; Harrington et al. 2004; Lenz et al. 2011).

\section{Recolonisation phase}

PZs 1, 2 und 3a represent the recolonisation phase, in which mainly pioneering plants colonised the crater area. Ferns like Schizaeaceae (Leiotriletes spp., Trilites spp.) and Polypodiaceae (Laevigatosporites spp.) in various combinations were important in the initial herbaceous communities of PZ 1 colonising the crater walls and the shoreline (Fig. 10b). Due to a rapid dispersal of spores by wind and reproduction via gametophytes, ferns flourished at the beginning probably without competitors (Lenz et al. 2007). Accordingly, they have repeatedly been recorded today as early colonisers of 

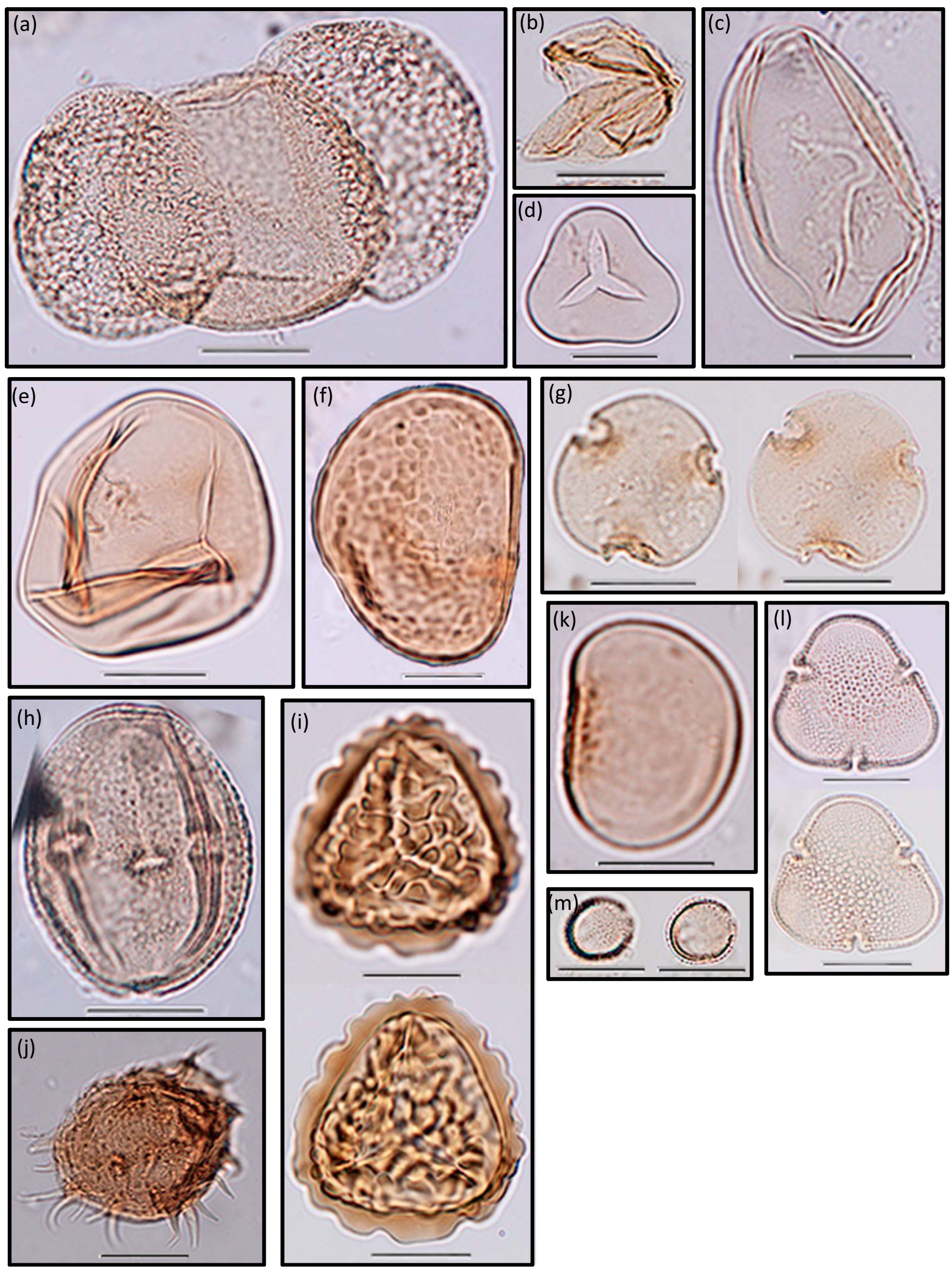
Fig. 8 Pollen and spores from the lacustrine record at Lake Offenthal. The scale bar represents $20 \mu \mathrm{m}$. Slide numbers and related depths are given in brackets. a Pityosporites labdacus (Pinaceae; Off-64, $21.00 \mathrm{~m}$ ); b Inaperturopollenites dubius (Cupressaceae; Off-64, $21.00 \mathrm{~m}$ ); c Inaperturopollenites magnus (Cupressaceae; Off-152, $16.60 \mathrm{~m}$ ); d Leiotriletes microadriennis (Schizaeaceae; Off-62, $21.32 \mathrm{~m}$ ); e Leiotriletes maxoides (Schizaeaceae; Off-64, $21.00 \mathrm{~m}$ ); f Verrucatosporites favus (Polypodiaceae; Off-62, $21.32 \mathrm{~m}$ ); g Intratriporopollenites microinstructus (Malvaceae; Off-88, $19.80 \mathrm{~m}$ ); h Tricolporopollenites marcodurensis (Vitaceae; Off-62, $21.32 \mathrm{~m}$ ); i Polypodiaceoisporites lusaticus (Polypodiaceae; Off-88, $19.80 \mathrm{~m}$ ); j Echinatisporites longiechinatus (Selaginellaceae; Off-126, 17.90 m); k Punctatosporites palaeogenicus (Polypodiaceae; Off-126, $17.90 \mathrm{~m}$ ); l Bombacacidites sp. (Malvaceae; Off-99, $19.25 \mathrm{~m}$ ); m Tricolporopollenites microreticulatus (Oleaceae; Off-99, 19.25 m);

volcanic sites in the tropics, such as the Krakatoa (Richards 1996) or Motmot (Harrison et al. 2001). The well-known spike of fern spores at the Cretaceous/Paleogene boundary is another example of initial recolonisation of deeply devastated habitats by ferns (Tschudy et al. 1984; Fleming and Nichols 1990).

Later during PZ 2, Restionaceae followed and invaded the herbaceous communities since their pollen (Milfordia spp.) is only found in this part of the lacustrine succession and disappeared finally in PZ 3b. On Krakatoa and on the crater walls of volcanoes on Papua New Guinea, grasses followed the early fern communities on volcanic substrates (Taylor 1957). However, since grasses were rare during the Eocene but pollen of Restionaceae is regularly present in Europe, they may have occupied the role of today's grasses and were growing within the marginal vegetation at Messel and Offenthal (Lenz et al. 2007, this paper). Today, they grow preferably in lowlands on wet and nutrient-poor soils and favour seasonally wet habitats that may dry out each year (Heywood 1993). Therefore, at Lake Offenthal, relatively shallow habitats may have existed at the lake shore which were occasionally flooded during phases of a higher lake level (Fig. 10b). Furthermore, the relatively high values for Cupressaceae (Inaperturopollenites spp.) and Nyssaceae (Nyssapollenites spp., Fig. 9s) during the recolonisation phase indicate that populations of Nyssa and Taxodium existed around the lake. The littoral zones in front of the swampy margin were colonised by sustaining floating and submersed aquatic plants such as Hydrocharitaceae (Punctilongisulcites microechinatus), which occur regularly in PZ 2 and the succeeding palynozones.

The high proportion of allochthonous pollen and spores derived from the regional vegetation such as pollen of Fagaceae (Tricolpopollenites liblarensis, Tricolporopollenites cingulum) as well as Juglandaceae (Plicatopollis spp.) already at the beginning of the recolonisation phase is striking. This indicates that the surrounding forest was not affected to a greater distance by the phreatomagmatic explosion and maar formation at
Offenthal. During the recolonisation phase, algae established within the lake. Botryococcus is regularly found and became temporarily frequent in PZ 2 (Fig. 5), but disappeared later in PZ 3. This shows that the distribution of Botryococcus is restricted to the holomictic lake phase. Formation of a stratified lake during the following recovery phase may have altered the water chemistry, as Botryococcus favours alkaline conditions (Wetzel 1983). Furthermore, Botryococcus prefers oligotrophic conditions (Jankovská and Komárek 2000), suggesting that nutrient supply to the lake was limited during PZ 2.

\section{Recovery phase}

PZs 3b, 4 and 5 represent the recovery phase (Fig. 10c). Palynomorphs from an initial pioneer vegetation decrease (ferns, e.g. Trilites spp.) or disappear completely (Restionaceae) (Fig. 5). Botanically, this reflects the change from a pioneering vegetation to a mixed forest successively invading the area around the crater. Therefore, elements of the (para)tropical rainforest increase significantly and dominate the pollen assemblages (Fig. 5), such as the pollen of Fagaceae (Tricolporopollenites cingulum and Tricolpopollenites liblarensis), Juglandaceae (Plicatopollis spp. and Plicapollis spp.) and Eucommiaceae (Tricolpo(ro)pollenites parmularius). Since all of these taxa have already been recorded in lower numbers in the samples from the previous recolonisation phase, a gradual colonisation of the crater area by the thermophilic forest is documented. Some of the arboreal elements, such as Celtis (Cannabaceae, Fig. 9d), are slightly decreasing in their abundance compared with the recolonisation phase where they are even found in the earliest zones. This could indicate that some trees may have advanced into the crater area more quickly.

However, since some of the pioneering plants, such as some of the ferns, still persist in low numbers during the recovery phase, the transition to a complete reoccupation of the crater area by the forest vegetation with the total disappearance of the pioneer elements, as seen at Messel (Lenz et al. 2007), is not documented at Offenthal. A final climax state has therefore not been reached in the vegetation as recorded in the succession preserved at Offenthal.

Although most fern spores disappear throughout the recovery phase, some spores remain very abundant and show frequency maxima in PZs $3 \mathrm{~b}$ and 4. This is especially true for Leiotriletes spp. which may have been derived from Lygodium (Schizaeaceae). They are known today as lightloving climbers (Tryon and Tryon 1982) and from volcanic terrains where they colonise open and disturbed habitats (Collinson 2002). Occasional collapse of minor sections of the crater wall or falling trees may have resulted in new open habitats which were then colonised by Lygodium-type ferns. 

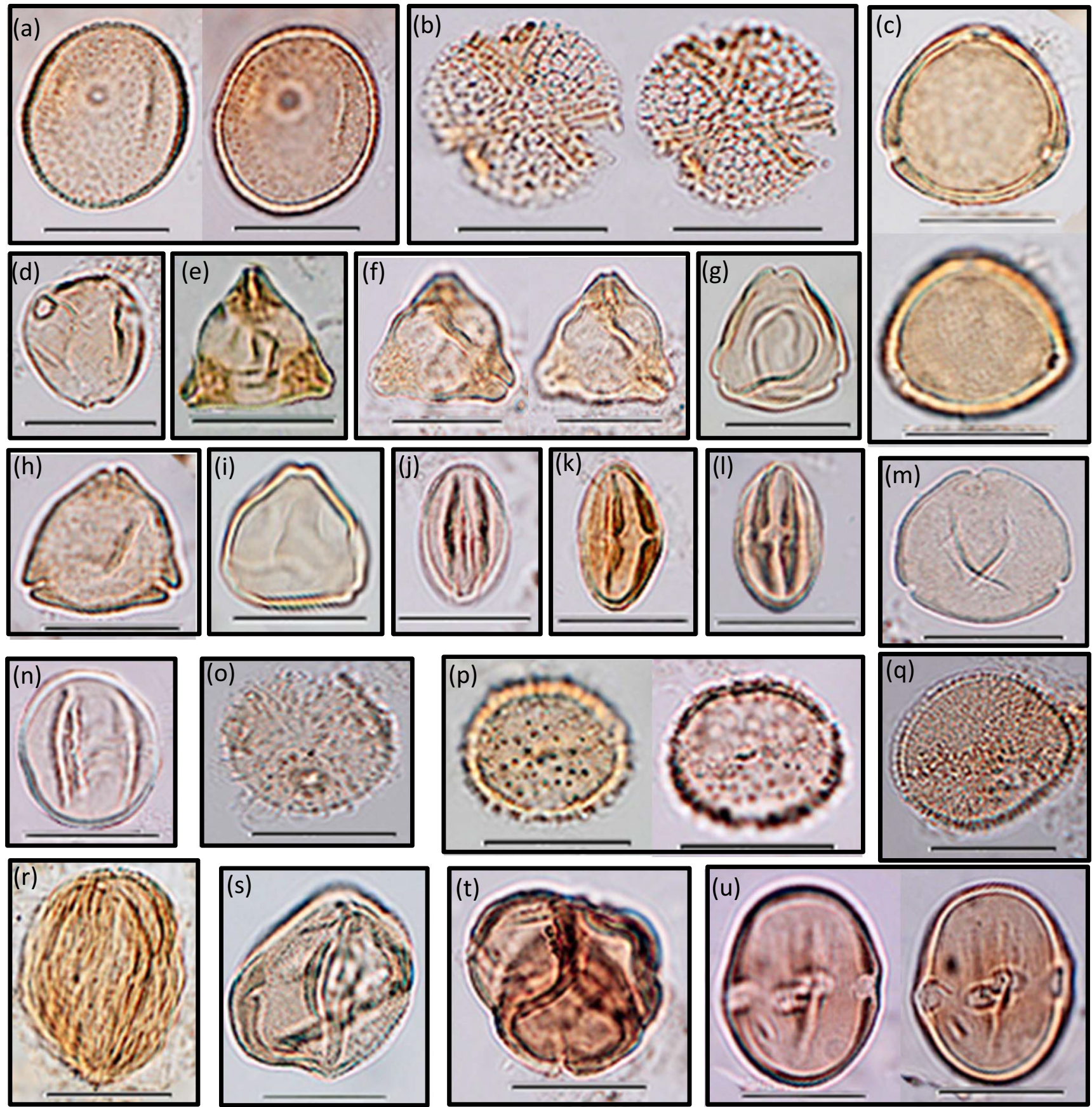

Fig. 9 Pollen and spores from the lacustrine record at Lake Offenthal. The scale bar represents $20 \mu \mathrm{m}$. Slide numbers and related depths are given in brackets. a Milfordia minima (Restionaceae; Off-118, $18.30 \mathrm{~m}$ ); b Tricolpopollenites vegetus (Hamamelidaceae; Off-126, $17.90 \mathrm{~m}$ ); c Subtriporopollenites magnoporatus (unknown botanical affinity; Off62, $21.32 \mathrm{~m}$ ); d Celtipollenites intrastructurus (Cannabaceae; Off-118, $18.30 \mathrm{~m}$ ); e Nudopollis terminalis hastaformis (Normapolles with unknown botanical affinity; Off-62, $21.32 \mathrm{~m}$ ); f Plicapollis pseudoexcelsus turgidus (Juglandaceae?; Off-64, $21.00 \mathrm{~m}$ ); g Playcaryapollenites semicyclus (Juglandaceae; Off-118, $18.30 \mathrm{~m}$ ), h Triatriopollenites rurensis (Myricaceae; Off-64, $21.00 \mathrm{~m}$ ); i Plicatopollis sp. (Juglandaceae; Off-99, 19.25 m); j Tricolpopollenites liblarensis (Fagaceae, Fabaceae, Combretaceae, Verbenaceae; Off-99, $19.25 \mathrm{~m}$ ); k, I Tricolporopollenites cingulum (Fagaceae; Off-62, $21.32 \mathrm{~m}$; Off-64, $21.00 \mathrm{~m}$ ); m Playcaryapollenites platycaryoides (Juglandaceae; Off-152, $16.60 \mathrm{~m}$ ); $\mathbf{n}$ Tricolpo(ro)pollenites parmularius (Eucommiaceae; Off-62, $21.32 \mathrm{~m}$ ); o Porocolpopollenites rarobaculatus (Symplocaceae; Off-126, 17.90 m); p Compositoipollenites rhizophorus (Icacinaceae; Off-99, 19.25 m); q Emmapollis pseudoemmaensis (Chloranthaceae; Off-155, $16.45 \mathrm{~m}$ ); r Tricolporopollenites sole de portai (Anacardiaceae, Rosaceae; Off-99, 19.25 m); s Nyssapollenites kruschii (Nyssaceae; Off-52, $22.10 \mathrm{~m}$ ); t Ericipites ericius (Ericaceae; Off-88, $19.80 \mathrm{~m}$ ); u Tetracolporopollenites sapotoides (Sapotaceae; Off- $80,20.20 \mathrm{~m}$ ) 
c)

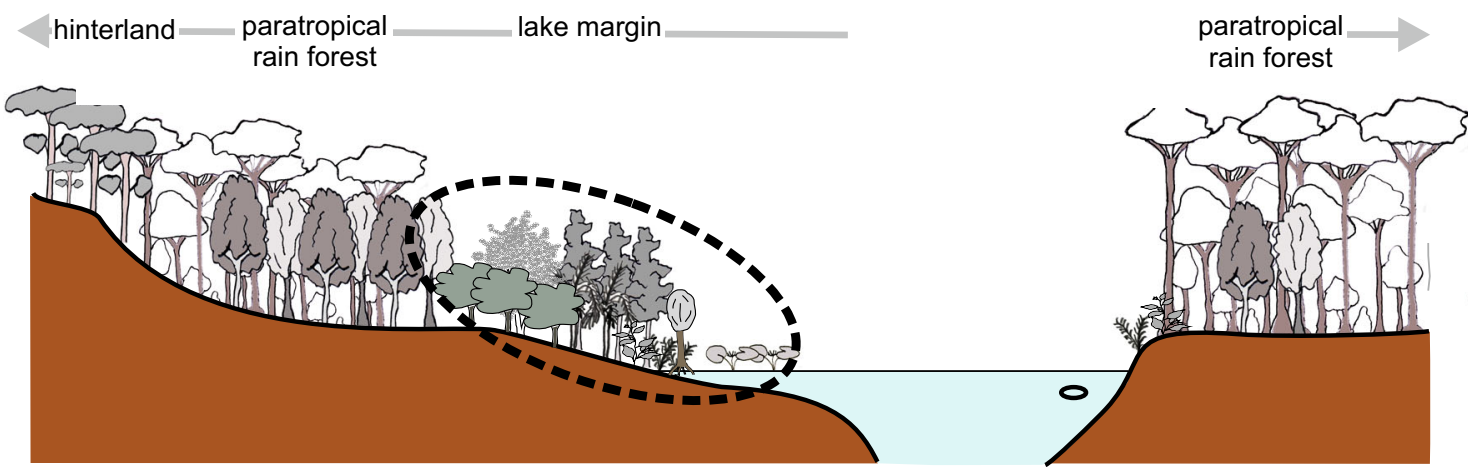

b)

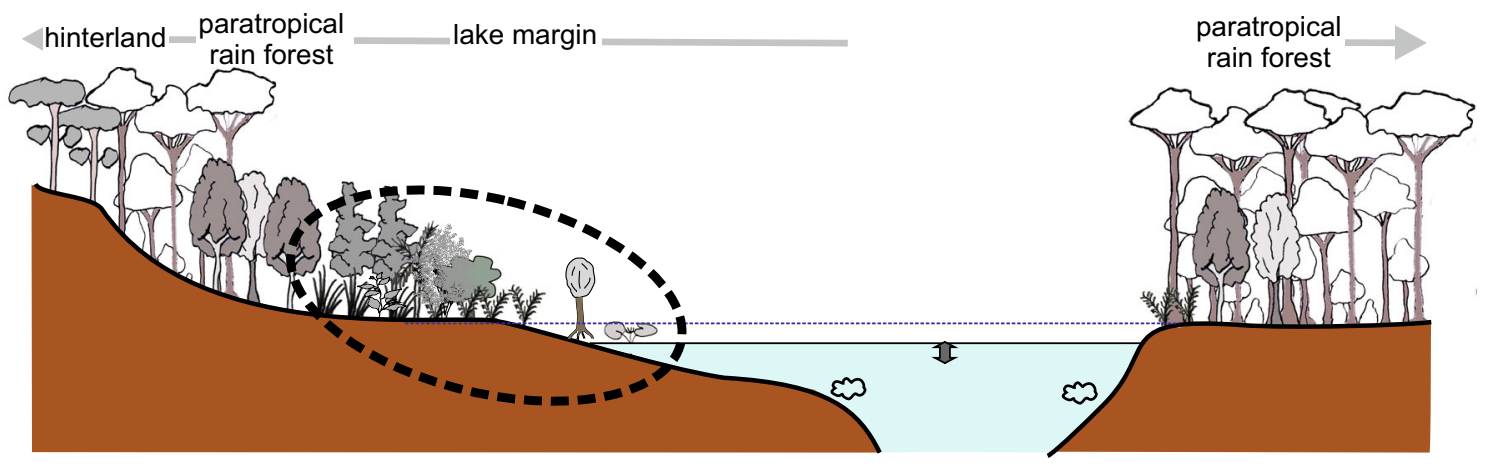

a)
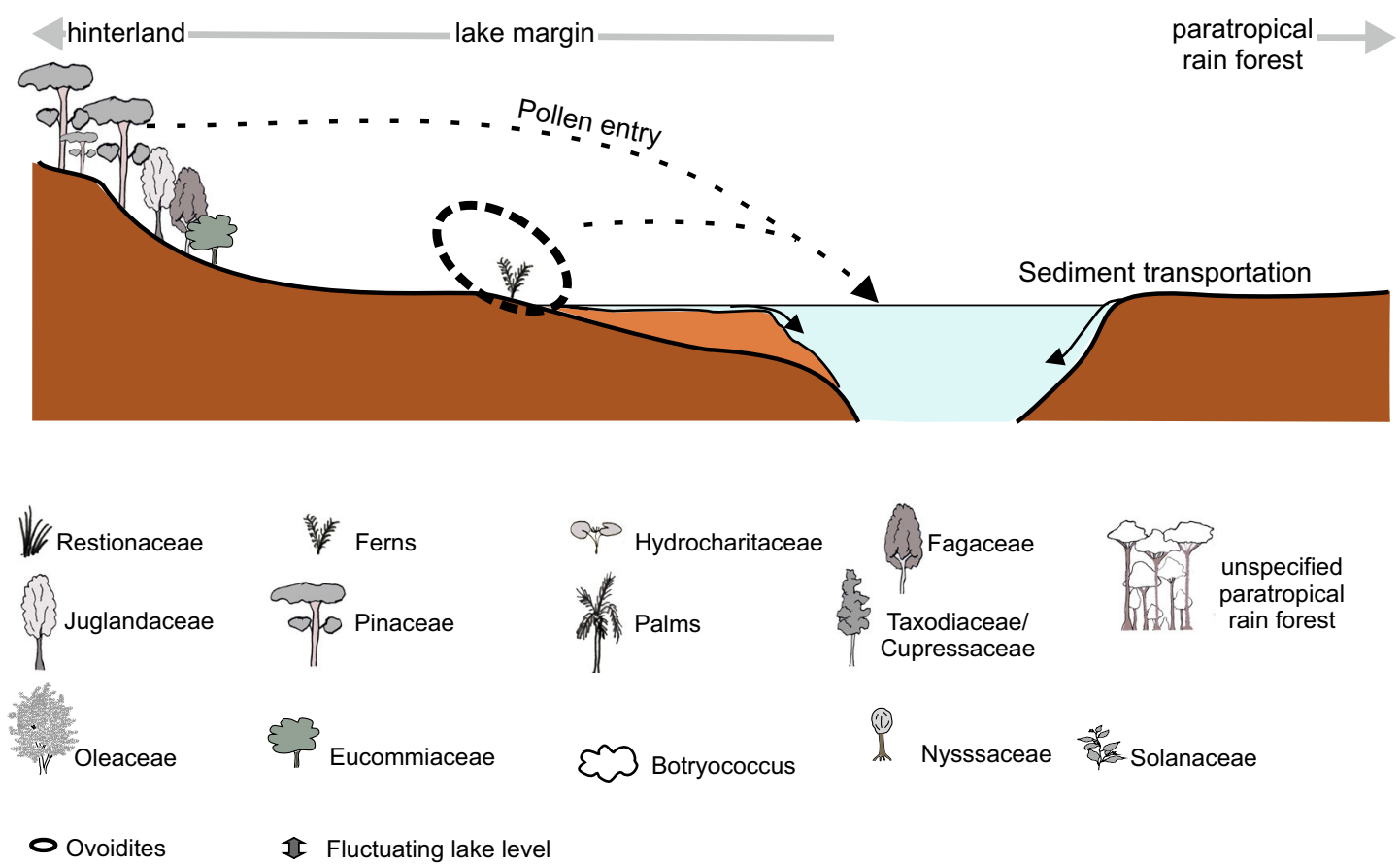

Fig. 10 Reconstruction of the palaeoenvironment in the lacustrine succession of the Offenthal maar lake. The lake basin model is based on Felder and Gaupp (2006) 
It is important that the change from the recolonisation to the recovery phase coincides with the change from a holomictic to a seasonally stratified lake that is documented in the change in lithology between LZs 4 and 5 (Fig. 3). This indicates that a dense vegetation with deeply rooting trees led to a stabilisation of the crater walls. As a consequence, sediment input decreased to a minimum and mixing of the water body in the lake due to slope failure ceased. Therefore, the main influencing factor for the composition of the vegetation as well as the depositional conditions in the maar lake, which is represented by axis 1 of the NMDS (Fig. 7), has been the stability of the crater walls. Correspondingly, the pioneer elements and samples of the holomictic lake phase are plotted on the right side of the NMDS plot separate from elements of the rainforest and samples from the period with a stratified lake on the left side of the NMDS plot.

Among the algal flora in the lake, the disappearance of Botryococcus and the regular occurrence of Zygnemataceae of the Spirogyra type as recorded by their cysts (Ovoidites sp.) are noteworthy. Since Zygnemataceae prefer shallow and stagnant water (Colbath 1996; van Geel 2002), this can probably also be explained by the stabilisation of the crater slopes and the formation of an at least temporarily stratified lake with low turbidity and a shallow shoreline.

\section{Comparison of the maar lakes at Offenthal and Messel}

Compared with the nearby maar lake of Messel, the maar lake at Offenthal has only a third of the diameter and size (Felder et al. 2001). Therefore, the thickness of the lacustrine filling at Messel is by a factor of 8 higher than in Offenthal. Nevertheless, Lake Offenthal and Lake Messel are generally characterised by a similar succession of lithological units starting with volcanic material (Fig. 2) providing proof that the respective lake sediments have been deposited within maar structures which were formed by one or more phreatomagmatic eruption(s) (Felder et al. 2001; Liebig 2001; Felder and Harms 2004).

At Messel, $230 \mathrm{~m}$ of lacustrine sediments have been cored (Felder and Harms 2004) while there are only $29 \mathrm{~m}$ in the core from Offenthal. The different thicknesses imply that a significant longer period of time is documented in the lacustrine filling at Messel.

In Messel, the lower $90 \mathrm{~m}$ of the lacustrine maar filling are composed of clastic sediments (Lower Messel Formation), which represent the holomictic stage of the lake. In the upper part of the Lower Messel Formation, layers of oil shale become more frequent and dominate above $139 \mathrm{~m}$, reflecting the change from holomictic to meromictic conditions in the lake. In Offenthal, a similar sedimentary succession is found at the base of the lacustrine filling, albeit with a significantly lower thickness. Only in the lower $7 \mathrm{~m}$ of the lacustrine sequence (LZ 3), sands and silt, which are mostly graded, as well as turbidites dominate. The first layers of bituminous shale appear at a depth of $22 \mathrm{~m}$, which, as in Messel, indicate an increasing stability of the crater slopes with at least short meromictic phases.

The deposition of the classical "Messel oil shale" of the Middle Messel Formation started at a depth of $110 \mathrm{~m}$ in the core from Messel. This is a finely laminated, highly bituminous shale which was formed during the stable meromictic phase of the lake (Felder and Harms 2004) and resulted from annual algal blooms of the coccal green alga Tetraedron minimum (Irion 1977; Goth 1990; Lenz et al. 2010, 2015). The upper $14 \mathrm{~m}$ of the lacustrine succession at Offenthal also show some kind of a bituminous shale (LZs 5 and 6), which is often also finely laminated and appears similar to the Messel oil shale. However, Tetraedron has not been recovered by SEM studies of selected samples, and an annual varve-like stratification cannot be proven in this portion of the Offenthal core. Interestingly, sponge spicules were frequently found in some of the Offenthal samples.

Accordingly, different depositional conditions can be assumed for both lakes, which is confirmed by the isotopic values of siderite ( $\delta^{13}$ carbon and $\delta^{18}$ oxygen) from both lakes (Felder and Gaupp 2006). At Offenthal, intermediate carbon isotopic values in combination with the oxygen isotopic signature may be regarded as typical for a holomictic lake with annual overturn (Felder and Gaupp 2006) (Fig. 2). The high values for $\delta^{18} \mathrm{O}$ and for $\delta^{13} \mathrm{C}$ at Messel with a comparatively wide range are typical for a meromictic lake with stagnant water at the bottom (Felder and Gaupp 2006).

In order to compare the vegetation around the maar lake of Offenthal with the almost coeval vegetation in the vicinity of the nearby maar lake at Messel, NMDS was carried out including the 68 samples from Offenthal and 598 samples from core Messel 2001 (Lenz and Wilde 2018).

In the ordination space of the NMDS, the samples from Messel are generally ordered from right to left reflecting the stratigraphical succession of different vegetational stages and indicating a gradual and continuous change in the composition of the vegetation (Fig. 11a). The oldest samples from Lake Messel from the Early Initial Lake Phase (EILP; Lenz et al. 2007) are plotted at the positive end of NMDS axis 1 mainly in the lower right corner of the ordination space (Fig. 11a). They are preferentially characterised by fern spores, which occur in high diversity in the EILP. Accordingly, trilete spores, such as Cictricosisporites spp., Ischyosporites sp. and Punctatosporites sp., as well as monolete spores, such as Laevigatosporites spp. and Verrucatosporites spp., are plotted at the positive end of NMDS axis 1 indicating that these spores reach their maximum values in samples from the EILP (Fig. 11b). The samples reflect the beginning of the recolonisation of the devastated area around Lake Messel by a pioneer vegetation (Lenz et al. 2007; Lenz and Wilde 2018). In samples from the Late Initial Lake Phase (LILP; 
a)

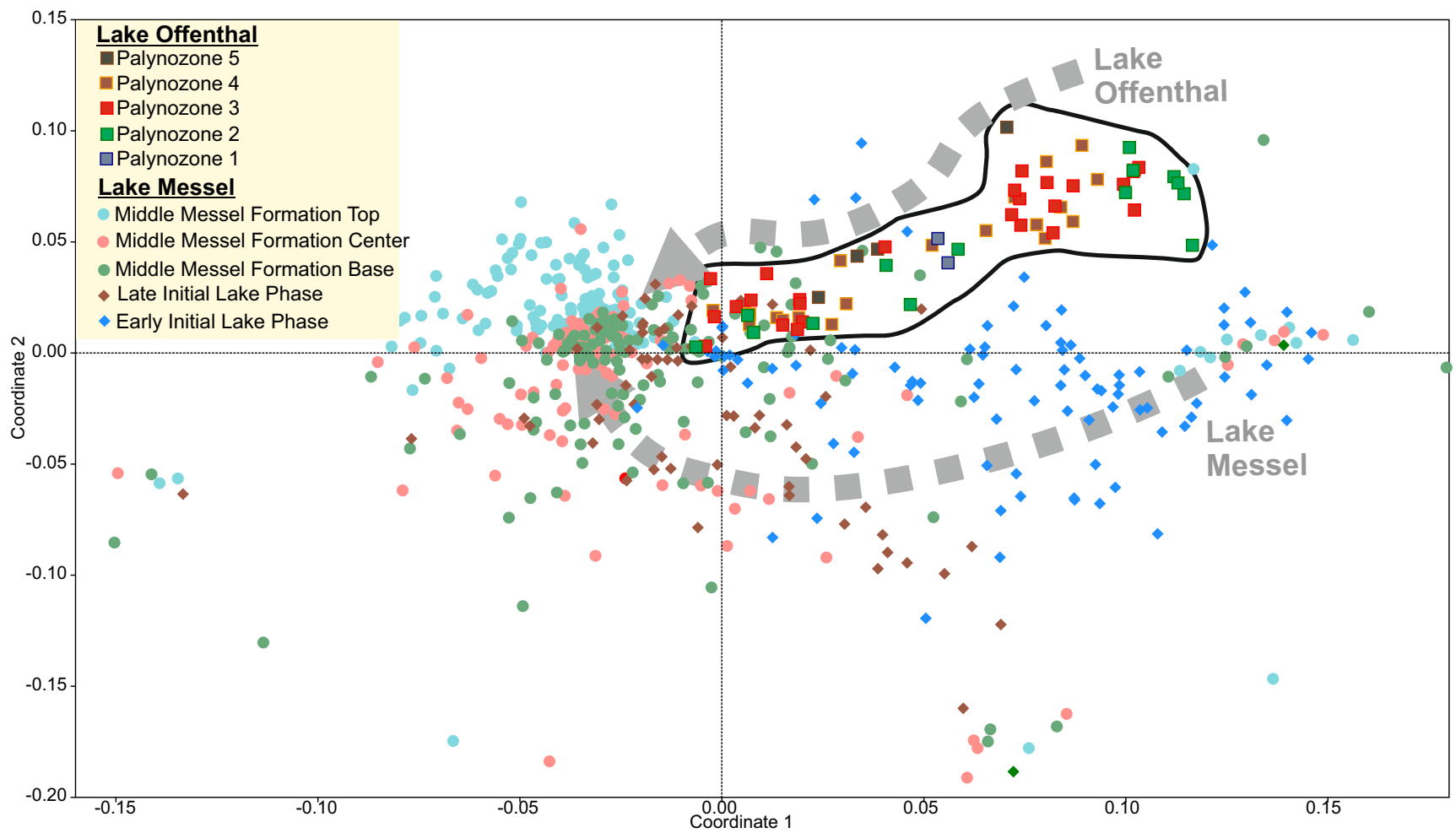

b)

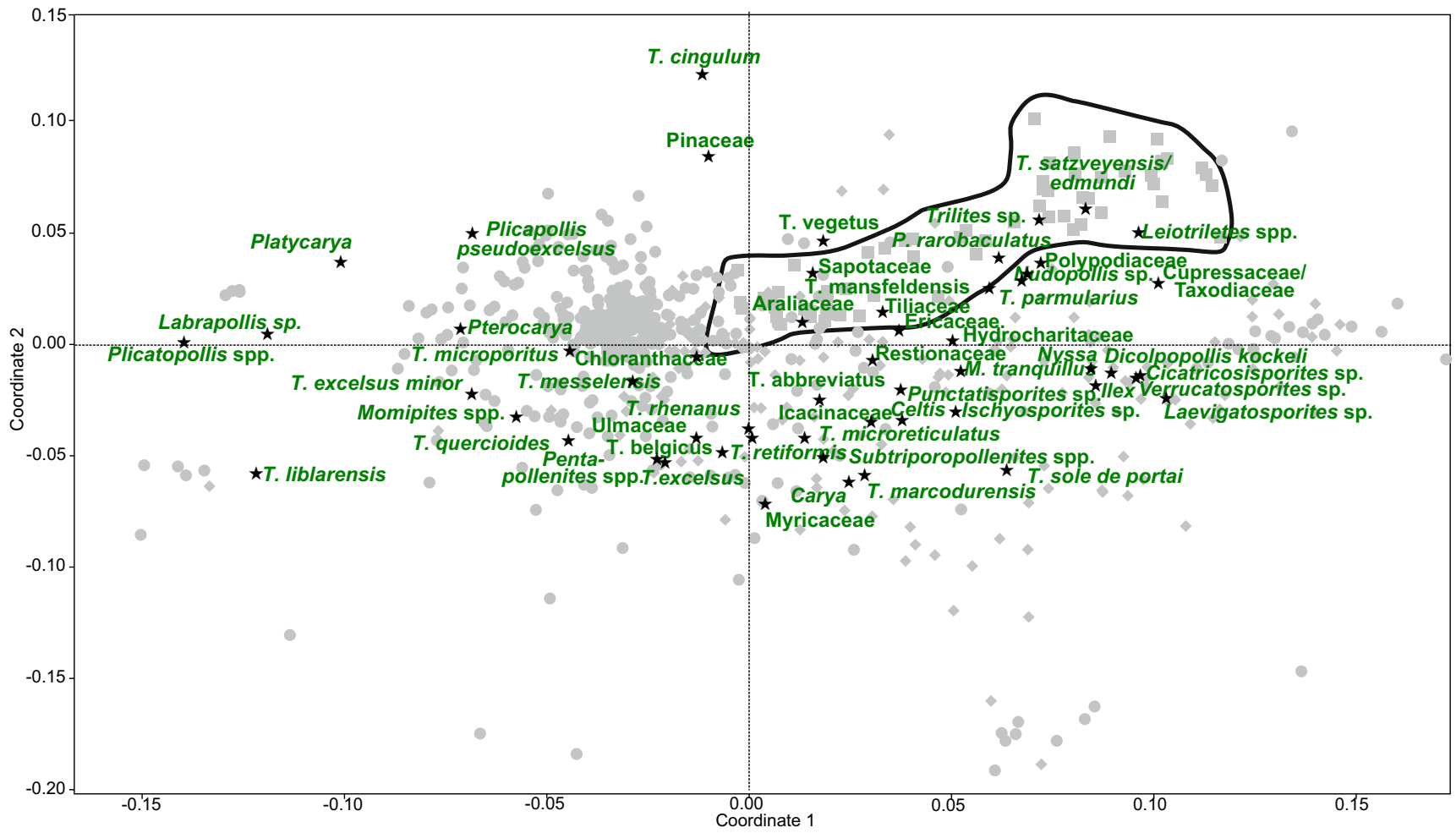

Fig. 11 Non-metric multidimensional scaling (NMDS) of palynological data of 68 samples from the lacustrine succession of the Offenthal maar lake and 598 samples from the lacustrine succession of the Messel maar lake using the Bray-Curtis dissimilarity and the Wisconsin double standardised raw data values. a Scatter plot of the first two axes showing the arrangement of samples. The different symbols represent samples from the different palynozones at Offenthal and phases at Messel (see Lenz and Wilde 2018). b Scatter plot of the first two axes showing the arrangement of taxa. The dots represent the different samples (see a) 
Lenz et al. 2007), which are mainly plotted in the centre of the ordination space (Fig. 11a), the spores decrease significantly in frequency. Characteristic elements that reach their abundance maximum in the LILP at Messel are, for example, Restionaceae (Milfordia sp.), Juglandaceae (Carya), Cannabaceae (Celtis), Ulmaceae and Myricaceae (Fig. 11b). The pioneer vegetation almost completely disappeared at the end of the LILP and was replaced by a mixed forest indicating the termination of recolonisation around the maar lake at Messel (Lenz et al. 2007; Lenz and Wilde 2018). Samples from the succeeding Middle Messel Formation (MMF) are plotted (Fig. 11a) to the left, negative side of NMDS axis 1 with a gradual change from the base to the top (Lenz et al. 2011; Lenz and Wilde 2018) (Fig. 11a). Furthermore, a general separation of samples from the MMF along NMDS axis 2 is obvious (Fig. 11a). The MMF is characterised by the dominance of pollen of the juglandaceous alliance (Plicatopollis spp., Platycaryapollenites spp., Plicapollis pseudoexcelsus, Pterocaryapollenites sp., Momipites spp.) as well as of fagaceous pollen (Tricolporopollenites cingulum, Tricolpopollenites liblarensis), which are all plotted on the negative side of NMDS axis 1 (Fig. 11b). These elements represent a thermophilic climax vegetation at Messel, which is typical for inland sites of Western and Central Europe during the middle
Eocene greenhouse climate (Mai 1981, 1995; Schaarschmidt 1988; Wilde 1989; Collinson et al. 2012).

The continuous gradual compositional changes within the vegetation communities at Messel during the recolonisation of the crater area and the establishment of a climax vegetation are comparable with the vegetational changes at Lake Offenthal. Therefore, the evolution of the vegetation at Lake Messel can be assigned to similar vegetational phases. The recolonisation phase is characterised by a herbaceous and shrubby pioneer vegetation represented by the EILP of the Lower Messel Formation (Lenz et al. 2007). The recovery phase during the LILP is marked by the reoccupation of the crater area by a mixed tropical rainforest and within the lake by a change from holomictic to meromictic conditions (Lenz et al. 2007). However, the forest of the recovery phase differs in composition and diversity from the climax vegetation which is established later in the climax phase during the subsequent Middle Messel Formation (Lenz and Wilde 2018).

The NMDS reveals that palynomorph assemblages from Offenthal are slightly different compared with the assemblages of the recolonisation phase at Messel (Figs. 11 and 12), because the samples are separated from the samples of the EILP in the upper right corner of the NMDS plot. This indicates that the composition of the pioneer vegetation was

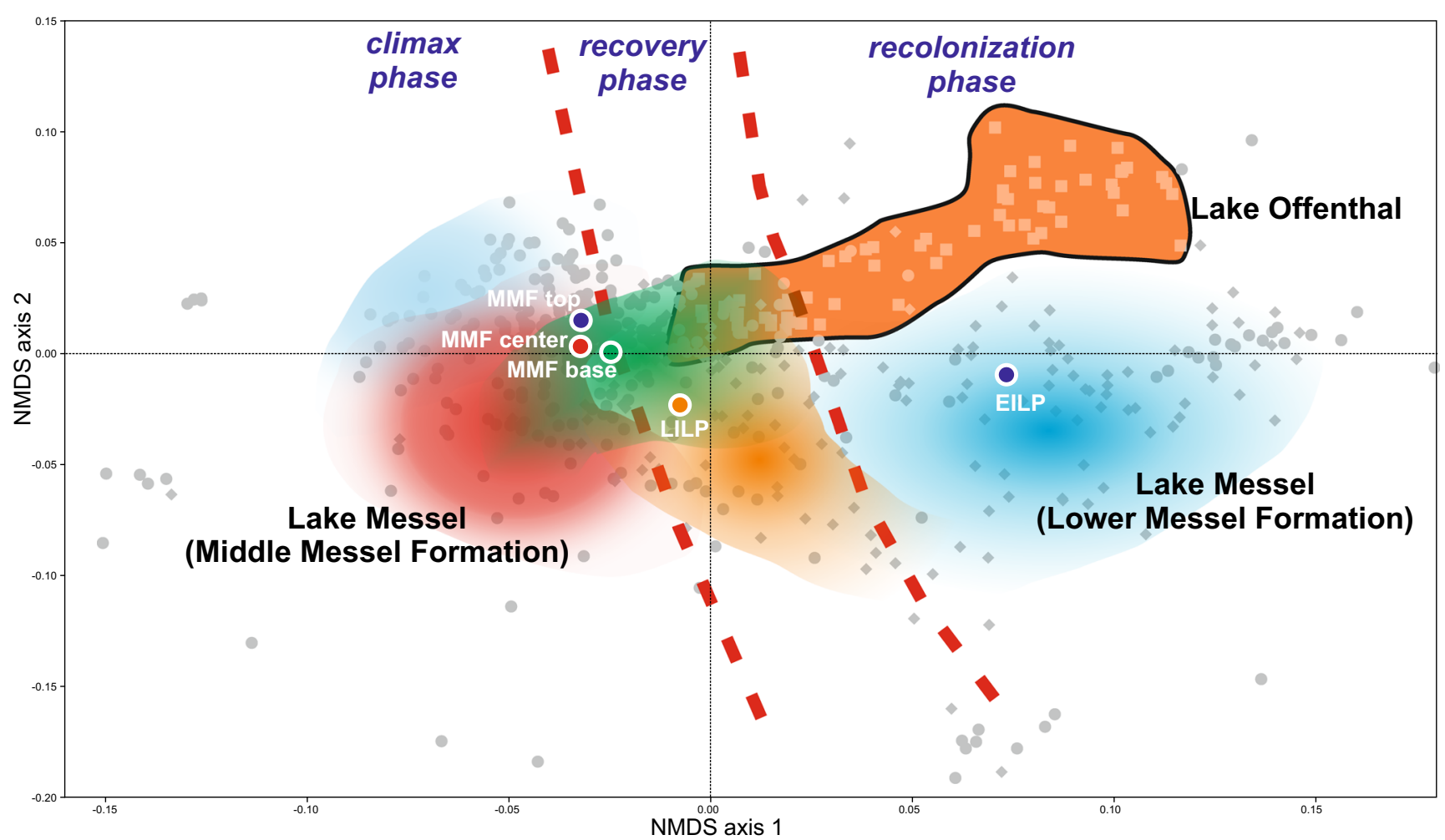

Fig. 12 Non-metric multidimensional scaling (NMDS) of palynological data of 68 samples from the lacustrine succession of the Offenthal maar lake and 598 samples from the lacustrine succession of the Messel maar lake showing the different vegetational phases during the recolonisation of the volcanically disturbed sites. The coloured dots indicate the median NMDS scores of the different vegetation phases at Messel (see Lenz and Wilde 2018) 
slightly different during the recolonisation of the crater areas at Offenthal and Messel. However, differences mainly correspond to the composition of the fern communities. At Offenthal, fern spores of the Schizaeaceae, such as Trilites spp. or Leiotriletes spp., are more abundant than spores of the Polypodiaceae, such as Laevigatosporites spp. and Verrucatosporites spp., which are common in the EILP at Messel (Lenz et al. 2007). Another spore of the Schizaeaceae (Cicatricosisporites spp.) occurs frequently during the EILP at Messel but is completely absent at Offenthal. However, other elements of the recolonisation phase such as Restionaceae (Milfordia spp.) are important elements at both sites. Also, general vegetational trends such as the establishment of a Nyssa/Taxodium community relatively early at the beginning of the recolonisation phase are seen at Offenthal and Messel.

Therefore, the recolonisation of the devastated areas at both sites follows a similar pattern with palynological assemblages that reflect typical vegetation communities for the recolonisation of Eocene maar lakes. This is supported by similar general trends which are today found in the recolonisation of volcanically disturbed sites, e.g. the Krakatoa (Richards 1996). Slight differences between Offenthal and Messel, for example in the composition of the fern communities, are probably related to local factors.

Most samples from the recovery phase at Offenthal are plotted in the NMDS with samples from the recovery phase at Messel (LILP) together in the centre of the ordination space (Fig. 12) indicating that the forests, which re-occupied the crater areas of both maar lakes, had a similar composition. However, this is not surprising, as both lakes are almost coeval and located relatively close to each other on the Sprendlinger Horst (Fig. 1) which was most probably covered by a uniform zonal vegetation.

A fundamental difference between the successions at Offenthal and Messel becomes obvious in the NMDS by the fact that the samples from the Middle Messel Formation (MMF) are plotted on the left side of the ordination space clearly separate from all of the Offenthal samples on the right side (Fig. 12). During the MMF, at Messel, a robust climax vegetation existed for several hundred thousand years which was characterised by pollen assemblages without significant qualitative changes (Lenz et al. 2011; Lenz and Wilde 2018). Only quantitative changes in the dominance of individual pollen species occurred. Such a vegetation, which can be attributed to a climax phase and which follows the recovery phase in a natural vegetational succession by absence of further disturbance of the crater area, is not documented at Offenthal. The climax vegetation at Messel is dominated especially by fagaceous (Tricolporopollenites cingulum, Tricolpopollenites liblarensis) and juglandaceous (e.g. Plicatopollis spp. and Plicapollis spp.) plants (Lenz et al. 2011; Lenz and Wilde 2018). Although these pollen taxa are also very common in
Offenthal, they are not as dominant as in Messel indicating that the final climax phase is not reached in the succession at Offenthal.

At Offenthal, the maar lake was much smaller and thus the thickness of the sedimentary filling of the lake basin by a factor of 8 lower than at Messel. Therefore, probably a much shorter time interval is documented at Offenthal. Based on calculations of the sedimentation rate, it can be assumed that a time interval of 800 to $900 \mathrm{ka}$ is documented at Messel by the lacustrine succession of the Lower and Middle Messel Formations including a deposition time of c. $640 \mathrm{ka}$ for the MMF (Lenz et al. 2015). Due to the lack of an annual signature in the oil shale, a calculation of the time of deposition is impossible at Offenthal. Nevertheless, it can be assumed that a significantly shorter time was needed for the complete filling of the small lake basin, especially since the clastic sequences of LZs 3 and 4 with many turbidites were probably deposited in a very short time of a few hundred years. A climax phase such as the one at Messel is not documented at Offenthal, most probably since the succession is cut off by a Quaternary cover.

\section{Conclusion}

The nearly coeval phreatomagmatic eruptions at Offenthal and Messel on the Sprendlinger Horst in Southwestern Germany led not only to the formation of maar crater structures but also to destruction and disturbance of the Lower to Middle Eocene paratropical vegetation around. Based on the comparison of palynological assemblages as preserved in the maar lake sediments from cores at both localities, similar processes during the recolonisation of the volcanically disturbed sites can now be recognised.

During an initial phase, which is distinguished at Offenthal, pollen of the zonal vegetation was transported only in small amounts from the distance into the crater lake. Winddispersed pollen of Pinaceae or Cupressaceae and extremely rare grains of other elements from the forest, which survived in the distance, point to the composition of the vegetation prior to the eruption(s). In the succeeding recolonisation phase, which is preserved at Offenthal and Messel, plants can be attributed to a pioneering succession. The pioneering flora invaded the disturbed areas around the maar lakes in successional stages. Ferns flourished at the beginning without competitors and were followed by Restionaceae, both forming a herbaceous cover. Woody swamp elements such as Nyssa and Taxodium early established at the margin of the lakes. With increased stability of the slopes, the zonal vegetation reestablished around the lakes and within the crater area during the recovery phase. In both lakes, the increasing stability of the slopes is reflected sedimentologically by decreasing input of sediment causing the change from holomictic to 
meromictic conditions at Messel or at least to a seasonally stratified lake at Offenthal. In both lakes, this change is characterised by the first appearance of laminated oil shale. The succeeding climax phase which is only preserved in the Middle Messel Formation at Messel is characterised by a robust climax vegetation without further fundamental changes in the vegetation.

The recolonisation of different habitats such as the lake margin, the slopes of the crater wall and the disturbed areas around the lake reveals a similar pattern of distinct vegetational phases obviously representing the chronological succession of various plant communities at Messel and Offenthal. Therefore, both records can be regarded as textbook examples for the recolonisation of volcanically disturbed areas during the Paleogene greenhouse period of Central Europe.

Acknowledgements The help of Karin Schmidt, Palaeobotanical Section, Senckenberg Research Institute and Natural History Museum Frankfurt, in sampling and sample preparation is acknowledged. We also acknowledge the Department for Messel Research and Mammalogy, Senckenberg Research Institute and Natural History Museum Frankfurt, for supplying the core photographs of FIS/HLUG from the core B/98-BK 1E. Finally, we thank two reviewers, Dr. Torsten Utescher and Dr. Steven R. Manchester, for their comments and suggestions which greatly helped to improve this paper.

Funding information Open Access funding provided by Projekt DEAL. Our study has been carried out as a project funded by the Deutscher Akademischer Austauschdienst (DAAD) under the grant 11020754900347 including the $\mathrm{PhD}$ appointment of the first author.

\section{Compliance with ethical standards}

Conflict of interest The authors declare that they have no conflict of interest.

Open Access This article is licensed under a Creative Commons Attribution 4.0 International License, which permits use, sharing, adaptation, distribution and reproduction in any medium or format, as long as you give appropriate credit to the original author(s) and the source, provide a link to the Creative Commons licence, and indicate if changes were made. The images or other third party material in this article are included in the article's Creative Commons licence, unless indicated otherwise in a credit line to the material. If material is not included in the article's Creative Commons licence and your intended use is not permitted by statutory regulation or exceeds the permitted use, you will need to obtain permission directly from the copyright holder. To view a copy of this licence, visit http://creativecommons.org/licenses/by/4.0/.

\section{References}

Boulter, M. C., \& Hubbard, R. N. (1982). Objective paleoecological and biostratigraphic interpretation of Tertiary palynological data by multivariate statistical analysis. Palynology, 6(1), 55-68.
Bray, J. R., \& Curtis, J. T. (1957). An ordination of the upland forest communities of southern Wisconsin. Ecological Monographs, 27, 325-349.

Broothaerts, N., Verstraeten, G., Kasse, C., Bohncke, S., Notebaert, B., \& Vandenberghe, J. (2014). Reconstruction and semi-quantification of human impact in the Dijle catchment, central Belgium: a palynological and statistical approach. Quaternary Science Reviews, 102, 96110 .

Cohen, K. M., Finney, S. C., Gibbard, P. L., \& Fan, J. X. (2013). The ICS international chronostratigraphic chart. Episodes, 36, 199-204.

Colbath, G. K. (1996). Green and blue-green algae. Introduction. In J. Jansonius \& D. C. McGregor (Eds.) Palynology: principles and applications, 1, Principles (pp. 171-172). Dallas: American Association of Stratigraphic Palynologists Foundation.

Collinson, M. E. (2002). The ecology of Cainozoic ferns. Review of Palaeobotany and Palynology, 119, 51-68.

Collinson, M. E., Smith, S. Y., Manchester, S. R., Wilde, V., Howard, L. E., Robson, B. E., Ford, D. S., Marone, F., Fife, J. L., \& Stampanoni, M. (2012). The value of X-ray approaches in the study of the Messel fruit and seed flora. In T. Lehmann \& F. S. K.Schaal (Eds.) Messel and the terrestrial Eocene - Proceedings of the 22nd Senckenberg Conference.Palaeobiodiversity and Palaeoenvironments, 92(4), 403-416.

Cottam, G., Goff, F. G., \& Whittaker, R. H. (1978). Wisconsin comparative ordination, in Whittaker $\mathrm{RH}$, ed., Ordination of Plant Communities. Handbook of Vegetation Science, 5-2, 185-213.

Felder, M., \& Gaupp, R. (2006). The $\delta 13 \mathrm{C}$ and $\delta 18 \mathrm{O}$ signatures of siderite-a tool to discriminate mixis patterns in ancient lakes. Zeitschrift der Deutschen Gesellschaft für Geowissenschaften, 157, 397-410.

Felder, M., \& Harms, F. J. (2004). Lithologie und genetische Interpretation der vulkano-sedimentären Ablagerungen aus der Grube Messel anhand der Forschungsbohrung Messel 2001 und weiterer Bohrungen. Courier Forschungsinstitut Senckenberg, 252, 151-203.

Felder, M., Harms, F. J., \& Liebig, V. (2001). Lithologische Beschreibung der Forschungsbohrungen Gro $\beta$-Zimmern, Prinz von Hessen und Offenthal sowie zweier Lagerstättenbohrungen be Eppertshausen (Sprendlinger Horst, Eozän, Messel-Formation, SüdHessen). Geologisches Jahrbuch Hessen, 128, 29-82.

Fleming, R. F., \& Nichols, D. J. (1990). The fern-spore abundance anomaly at the Cretaceous-Tertiary boundary: a regional bioevent in western North America. Lecture Notes in Earth Sciences, 30, 351364

Gauch, H. G., \& Scruggs, W. M. (1980). Variants of polar ordination. Vegetatio, 40, 147-153.

Ghilardi, B., \& O'Connell, M. (2013). Fine resolution pollen analytical study of Holocene woodland dynamics and land use in north Sligo, Ireland. Boreas, 42(3), 623-649.

Goth, K. (1990). Der Messeler Ölschiefer- ein Algenlaminit. Courier Forschungsinstitut Senckenberg, 131, 1-143.

Gruber, G., \& Micklich, N. (2007). Messel-treasures of the Eocene. Darmstadt: Hessisches Landesmuseum.

Hammer, Ø., Harper, D. A. T., \& Ryan, P. D. (2001). PAST: paleontological statistics software package for education and data analysis. Palaeontologia Electronica, 4(1) https://palaeo-electronica.org/ 2001_1/past/issue1_01.htm.

Hammer, O., Harper, D. A. T., \& Ryan, P. D. (2006). Paleontological statistics, version 1.57.

Harms, F. J., Aderhold, G., Hoffmann, I., Nix, T., \& Rosenberg, F. (1999). Erläuterungen zur Grube Messel bei Darmstadt, Südhessen. Schriftenreihe der Deutschen Geologischen Gesellschaft, 8, 181-222.

Harrington, G., Kemp, S., \& Koch, P. (2004). Palaeocene-Eocene 
paratropical floral change in North America: responses to climate change and plant immigration. Journal of the Geological Society, 161(2), 173-184.

Harrison, R. D., Banka, R., Thornton, I. W. B., Shanahan, M., \& Yamuna, R. (2001). Colonization of an island volcano, Long Island, Papua New Guinea, and an emergent island, Motmot, in its caldera lake. II. The vascular Flora. Journal of Biogeography, 28, 1311-1337.

Heywood, V. H. (1993). Flowering plants of the world (Updated ed.). New York: Oxford University Press.

Irion, G. (1977). Der eozäne See von Messel. Natur und Museum, 107, 213-218.

Jacoby, W. (1997). Tektonik und Eozäner Vulkanismus des Sprendlinger Horstes, NE-Flanke des Oberrheingrabens. Schriftenreihe der Deutschen Geologischen Gesellschaft, 2, 66-67.

Jacoby, W., Wallner, H., \& Smilde, P. (2000). Tektonik und Vulkanismus entlang der Messeler-Störungszone auf dem Sprendlinger Horst: geophysikalische Ergebnisse. Zeitschrift der Deutschen Gesellschaft für Geowissenschaften, 151-154, 493-510.

Jankovská, V., \& Komárek, J. (2000). Indicative value of Pediastrum and other coccal green algae in palaeoecology. Folia Geobotanica, 35, $59-82$.

Janssen, C. R., \& Birks, H. J. B. (1994). Recurrent groups of pollen types in time. Review of Palaeobotany and Palynology, 82, 165-173.

Jardine, P. E., \& Harrington, G. J. (2008). The Red Hills Mine palynoflora: a diverse swamp assemblage from the Late Paleocene of Mississippi, USA. Palynology, 32(1), 183-204.

Juggins, S. (2007). C2 software for ecological and palaeoecological data analysis and visualization. User guide Version 1.5, p 73.

Kaiser, M. L., \& Ashraf, R. (1974). Gewinnung und Präparation fossiler Pollen und Sporen sowie anderer Palynomorphae unter besonderer Berücksichtigung der Siebmethode. Geologisches Jahrbuch, 25, 85-114.

Krumbiegel, G., Rüffle, L. \& Haubold, H. (1983). Das eozäne Geiseltal, ein mitteleuropäisches Braunkohlevorkommen und seine Pflanzenund Tierwelt. Neue Brehm-Bücherei, 273. A. Ziemsen, Wittenberg.

Kruskal, J. B. (1964). Nonmetric multidimensional scaling: a numerical method. Psychometrika, 29, 115-129.

Kuiper, K. F., Deino, A., Hilgen, F. J., Krijgsman, W., Renne, P. R., \& Wijbrans, J. R. (2008). Synchronizing rock clocks of Earth history. Science, 320, 500-504

Lenz, O. K. (2005). Palynologie und Paläoökologie eines Küstenmoores aus dem Mittleren Eozän Mitteleuropas Die Wulfersdorfer Flözgruppe aus dem Tagebau Helmstedt, Niedersachsen. Palaeontographica B, 271, 1-157.

Lenz, O. K., \& Wilde, V. (2018). Changes in Eocene plant diversity and composition of vegetation: the lacustrine archive of Messel (Germany). Paleobiology, 44(4), 709-735.

Lenz, O. K., Wilde, V., \& Riegel, W. (2007). Recolonization of a Middle Eocene volcanic site: quantitative palynology of the initial phase of the maar lake of Messel (Germany). Review of Palaeobotany and Palynology, 145, 217-242.

Lenz, O. K., Wilde, V., Riegel, W., \& Harms, F. J. (2010). A 600 k.y.record of El Niño-Southern Oscillation (ENSO): Evidence for persisting teleconnections during the Middle Eocene greenhouse of Central Europe. Geology, 38(7), 627-630.

Lenz, O. K., Wilde, V., \& Riegel, W. (2011). Short-term fluctuations in vegetation and phytoplankton during the Middle Eocene greenhouse climate: a 640-kyr record from the Messel oil shale (Germany). International Journal of Earth Sciences, 100, 1851-1874.

Lenz, O. K., Wilde, V., Mertz, D. F., \& Riegel, W. (2015). New palynology-based astronomical and revised $40 \mathrm{Ar} / 39 \mathrm{Ar}$ ages for the Eocene maar lake of Messel (Germany). International Journal of Earth Science, 104, 873-889.

Lenz, O. K., Wilde, V., \& Riegel, W. (2017). ENSO- and solar-driven sub-Milankovitch cyclicity in the Palaeogene greenhouse world; high-resolution pollen records from Eocene Lake Messel, Germany. Journal of the Geological Society, 174, 110-128.

Liebig, V. (2001). Neuaufnahme der Forschungsbohrungen KB 1, 2, 4 und 7 von 1980 aus der Grube Messel (Sprendlinger Horst, Südhessen). Kaupia, 11, 3-68.

Lutz, H., Kaulfuss, U., Wappler, T., Löhnertz, W., Wilde, V., Mertz, D. F., Mingram, J. F., Franzen, J. L., Frankenhäuser, H., \& Kozil, M. (2010). Eckfeld Maar: window into an Eocene terrestrial habitat in Central Europe. Acta Geologica Sinica, 84, 984-1009.

Mai, D.H. (1981). Entwicklung und klimatische Differenzierung der Laubwaldflora Mitteleuropas im Tertiär. Flora, 171, 525-582.

Mai, D. H. (1995). Tertiäre Vegetationsgeschichte Europas-Methoden und Ergebnisse. Jena: Gustav Fischer Verlag.

Mander, L., Kürschner, W. M., \& McElwain, J. C. (2010). An explanation for conflicting records of Triassic-Jurassic plant diversity. Proceedings of the National Academy of Sciences of the United States of America, 107, 15351-15356.

Mertz, D. F., \& Renne, P. R. (2005). A numerical age for the Messel fossil deposit (UNESCO World Heritage Site) derived from 40Ar/39Ar dating on a basaltic rock fragment. Courier Forschungsinstitut Senckenberg, 255, 67-75.

Minchin, P. R. (1987). An evaluation of the relative robustness of techniques for ecological ordination. Vegetatio, 69, 89-107.

Moshayedi, M., Lenz, O. K., Wilde, V., \& Hinderer, M. (2018). Controls on sedimentation and vegetation in an Eocene pull-apart basin (Prinz von Hessen, Germany): evidence from palynology. Journal of the Geological Society, 175, 757-773.

Nickel, B. (1996). Die mitteleozäne Mikroflora von Eckfeld bei Manderscheid/Eifel. Mainzer Naturwissenschaftliches Archiv. Beiheft, 18, 1-121.

Oksanen, J. (2007). Standardization methods for community ecology. Documentation and user guide for package Vegan, 1.8-6.

Oswald, W., Faison, E. K., Foster, D. R., Doughty, E. D., Hall, R. R., \& Hansen, B. C. S. (2007). Post-glacial changes in spatial patterns of vegetation across southern New England. Journal of Biogeography, $34,900-913$

Rampino, M. R., \& Koeberl, C. (2006). Comparison of Bosumtwi impact crater (Ghana) and Crater Lake volcanic caldera (Oregon, USA): implications for biotic recovery after catastrophic events. In C. Cockell, I. Gilmour, \& C. Koeberl (Eds.) Biological processes associated with impact events. (pp. 101-120). Berlin: Springer.

Renne, P. R., Balco, G., Ludwig, K. R., Mundil, R., Min, K. W., et al. (2011). Response to the comment by W.H. Schwarz, on "Joint determination of $40 \mathrm{~K}$ decay constants and $40 \mathrm{Ar} * 40 \mathrm{~K}$ for the Fish Canyon sanidine standard, and improved accuracy for $40 \mathrm{Ar} / 39 \mathrm{Ar}$ chronology" by PR Renne et al. (2010). Geochimica et Cosmochimica Acta, 75, 5097-5100.

Richards, P. W. (1996). The tropical rain forest: an ecological study (2nd ed.). Cambridge: Cambridge Univ. Press.

Riegel, W., \& Wilde, V. (2016). An early Eocene Sphagnum bog at Schöningen, northern Germany. International Journal of Coal Geology, 159, 57-70.

Riegel, W., Lenz, O. K., \& Wilde, V. (2015). From open estuary to meandering river in a greenhouse world: an ecological case study from Middle Eocene of Helmstedt, Northen Germany. Palaios, 30, 304-326.

Sabel, M., Bechtel, A., Püttmann, W., \& Hoernes, S. (2005). Palaeoenvironment of the Eocene Eckfeld maar lake (Germany): implication from geochemical analysis of the oil shale sequence. Organic Geochemistry, 36, 873-891.

Schaarschmidt, F. (1988). Der Wald, fossile Pflanzen als Zeugen eines warmen Klimas. In S. Schaal \& W. Ziegler (Eds.) Messel - ein Schaufenster in die Geschichte der Erde und des Lebens (pp. 27 52). Frankfurt am Main: Waldemar Kramer. 
Shepard, R. N. (1962a). Analysis of proximities: multidimensional scaling with an unknown distance function. I. Psychometrica, 27, 125140

Shepard, R. N. (1962b). Analysis of proximities: multidimensional scaling with an unknown distance function. II. Psychometrica, 27, 219 246.

Smith, K. T., Schaal, S. F. K., \& Habersetzer, J. (2018). Messel-an ancient greenhouse ecosystem. Senckenberg-Buch 80. Stuttgart: Schweizerbart'sche Verlagsbuchhandlung.

Taylor, B. W. (1957). Plant succession on recent volcanoes in Papua. Journal of Ecology, 45, 233-243.

ter Braak, C. J. F. (1995). Ordination. In Data analysis in community and landscape ecology (pp. 91-274). Cambridge: Cambridge University Press.

ter Braak, C. J. F., \& Looman, C. W. N. (1995). Regression. In R. H. G. Jongman, C. J. F. Ter Braak, \& O. F. R. Tongeren (Eds.) Data analysis in community and landscape ecology (pp. 29-77). Cambridge: Cambridge University Press.

Thiele-Pfeiffer, H. (1988). Die Mikroflora aus dem mitteleozänen Ölschiefer von Messel bei Darmstadt. Palaeontographica B, 211, $1-86$.

Thomson, P. W., \& Pflug, H. (1953). Pollen und Sporen des mitteleuropäischen Tertiärs. Gesamtübersicht über die stratigraphisch und paläontologisch wichtigen Formen. Palaeontographica B, 94, 1-138.

Tryon, R. M., \& Tryon, A. F. (1982). Ferns and allied plants with special reference to tropical America. New York: Springer-Verlag.

Tschudy, R. H., Pillmore, C. L., Orth, C. J., Gilmore, J. S., \& Knight, J. D. (1984). Disruption of the terrestrial plant ecosystem at the Cretaceous-Tertiary boundary, Western Interior. Science, 225, $1030-1032$.

Van Geel, B. (2002). Non-pollen palynomorphs. In Tracking environmental change using lake sediments (pp. 99-119). Dordrecht: Springer.

Van Tongeren, O. F. (1995). Data analysis or simulation model: a critical evaluation of some methods. Ecological Modelling, 78(1-2), 51-60.

Wetzel, R. G. (1983). Attached algal-substrata interactions: fact or myth, and when and how? In Periphyton of freshwater ecosystems (pp. 207-215). Dordrecht: Dr. W. Junk.

Wilde, V. (1989). Untersuchungen zur Systematik der Blattreste aus dem Mitteleozän der Grube Messel bei Darmstadt (Hessen, Bundesrepublik Deutschland). Courier Forschungsinstitut Senckenberg, $115,1-123$.

Publisher's note Springer Nature remains neutral with regard to jurisdictional claims in published maps and institutional affiliations. 